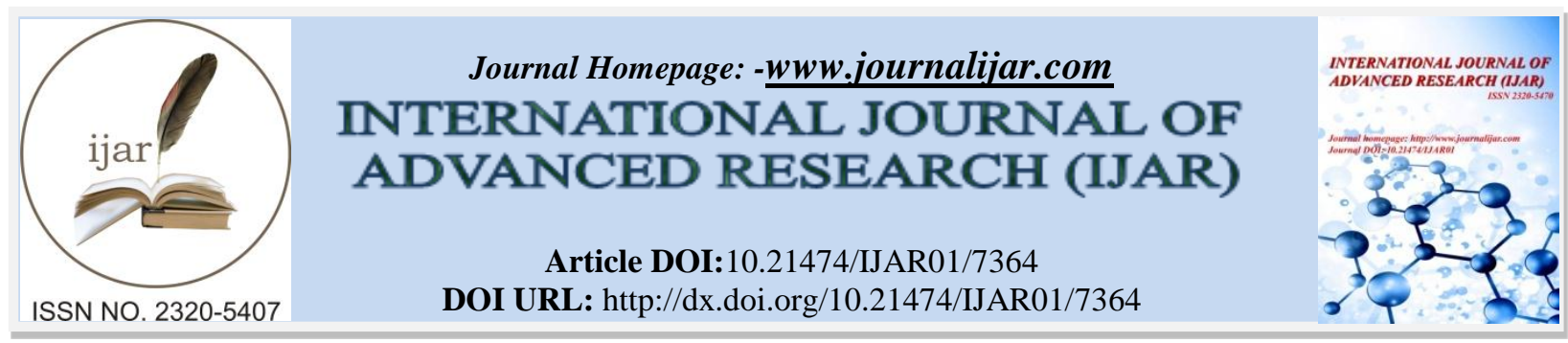

RESEARCH ARTICLE

\title{
ASSESSING THE NEXUS BETWEEN CORPORATE GOVERNANCE, CORPORATE SOCIAL RESPONSIBILITY AND CORPORATE REGULATION: THE WAY FORWARD FOR THE OHADA ZONE.
}

Dashaco John Tambutoh ${ }^{1}$ and Bande Gulbert Mbah Tarh'
1. Associate Professor (Maître de Conferences) of Law, University of Yaoundé II, Cameroon; Former Deputy Vice Chancellor in Charge of Internal Control and Evaluation, The University of Bamenda - Cameroon; Coordinator, Masters 2 in Intellectual Property Law jointly organized by the University of Yaoundé II (UYII), the World Intellectual Property Organization (WIPO) \& the African Intellectual Property Organization (OAPI).

2. Ph.D. in Law, Lecturer, FSJP, University of Maroua.

\section{Manuscript Info}

Manuscript History

Received: 07 May 2018

Final Accepted: 09 June 2018

Published: July 2018

\section{Keywords:-}

Nexus, Corporate Social Responsibility, Corporate Governance, Corporate Regulation, OHADA

\section{Abstract}

Encyclopaedic Corporate Governance (CG) is now a mainstream issue of concern in the business world. Yet, there has been no systematic investigation of CG practices in general, allowing for a distinction between the profit and non-profit organizations. In this regard, this article aims to investigate the nuances in the application of sound governance principles across different types of organizations in general, together with the understanding and applications of Corporate Social Responsibility (CSR) and Corporate Regulation (CR) in the context of the OHADA zone. With CSR envisages as a model of CG that extends the fiduciary duties from fulfilment of responsibilities towards the shareholders of the firm to fulfilment of analogous fiduciary duties towards all the firm's stakeholders. Thus, after considering the place of CSR in the debate about alternative CG modes, a full-fledged social contract foundation of the multi-stakeholder and multi-fiduciary model is present. The article, therefore, shows that CSR is a social norm that would endogenously emerge from the stakeholders' social contract seen as the first move in an equilibrium selection process that reaches the equilibrium state of a CG institution; and as a global trend involving corporations, states, international organizations and civil society organizations. Besides, the article portrays the trend of CSR in three ways: as a regulatory framework that places new demands on corporations; as a mobilization of corporate actors to assist the development aid of states and; as a management trend. With each of these portraits suggesting certain actors, relations, driving forces and interests as being central. These multiple identities may partially describe the trend's success, but could equally well describe its contestation, fragility and fluidity. Based on the argument that CSR is not just a fashion but rather the future from another angle, the article explicitly explores the nexus between CSR, CG and CR as appreciated in the OHADA zone. It also presents fresh insights into the applications of CG and CSR principles under the OHADA perspective that has not 
received systematic attention and consideration in the literature and, thus, provides policy recommendations to mainstream a viable CSR framework in the OHADA zone.

Copy Right, IJAR, 2018. All rights reserved.

\section{Introduction:-}

In point of fact, it could be affirmed that when a legal system is unreliable, the "shadow of the law" is faint to nonexistent. In such an environment, Corporate Governance (CG) may still have meaning, as may the larger principles of Corporate Social Responsibility (CSR) and Corporate Regulation (CR). Conversely, the meaning of these terms, and even our understanding of the business organization will be based on social reality, not on statutory constructs. In this light, the adoption of the uniform business law, ${ }^{1}$ known as OHADA ${ }^{2}$ by Cameroon and other sixteen-member states is very glaring. Correspondingly, the OHADA includes eight uniform acts which under the treaty automatically become part of each member-state's internal law. ${ }^{3}$ Besides, these laws are readily enforced in the member states because of the existence of formal legal structures, and sometimes because they conform to existing norms. However, sometimes they are ignored because they are incompatible with social norms. In this respect, entrepreneurs usually seek traditional means of accessing capital when the law is unpredictable because that context allows them to gain some predictability through traditional sources of social influence. Nevertheless, over time, the social realities have either reinforced or triggered the modification to the laws. In their turn, if the laws have any practical reality, they will influence social realities. The existence of this feedback loop is not news, but its application to developing countries' embryonic legal regimes offers a valuable tool to understand norms underlying legal principles. For example, as this process unfolds, social realities will mold societal understanding of the business organization's role in society. In this light, CSR is increasingly an essential issue for companies. ${ }^{4}$ It is a complex and multi-dimensional organisational phenomenon that is understood as the scope for which, and the ways in which, an organisation is consciously responsible for its actions and non-actions and their impact on its stakeholders. It is also increasingly being understood as a means by which companies may endeavour to achieve a balance between their efforts to generate profits and the societies that they impact in these efforts. ${ }^{5}$ Altogether, this article is divided into two parts, with the first part providing the synopsis of the conceptual framework of CSR, CG and $\mathrm{CR}$, and the second part considering the various concepts under the context of the OHADA legal framework and their practical appreciation and orientations.

\footnotetext{
${ }^{1}$ As of $11^{\text {th }}$ March 2017, the West African members are Benin, Burkina Faso, Côte d'Ivoire, Guinea, Guinea-Bissau, Mali, Niger, Senegal and Togo, and the Central African members are Central African Republic, Chad, Cameroon, Comoros, Congo, Equatorial Guinea, Gabon and Democratic Republic of Congo (DRC).

${ }^{2}$ L'Organisation pour l'Harmonisation en Afrique du Droit des Affaires. In English: The Organization for the Harmonization in Africa of Business Law.

${ }^{3}$ They cover the following disciplines (in order of adoption): company law and economic interest groupings; general commercial law; law of security interests and other encumbrances; simplified recovery procedure and methods of execution of judgments; bankruptcy and insolvency law; arbitration law; accounting law; law on transport of goods by road. See OHADA : Traite et Actes Uniformes Commentes et Annotes, Joseph Issa-Sayegh, Paul-Gérard Pougoué / Filiga Michel Sawdogo, ed. (2nd ed. 2000) (with 2003 addendum); see alsowww.ohada.com.

${ }^{4}$ Moon, J. and Vogel, D. (2008). 'Corporate Social Responsibility, Government, and Civil Society' in Andrew Crane et al. (eds), Oxford Handbook of Corporate Social Responsibility, 303; Vogel, D. (2005). The Market for Virtue: The Potential and Limits of Corporate Social Responsibility; Kakabadse, N., Rozuel, C. and Lee-Davies, L. (2005). 'Corporate Social Responsibility and Stakeholder Approach: A Conceptual Review' International Journal of Business Governance and Ethics, 1(4), pp. 277, 279.

${ }^{5}$ Clark, J. (2003). Worlds Apart: Civil Society and the Battle for Ethical Globalisation;Hutter, B. M. and O’Mahony, J. (2004). 'The Role of Civil Society Organisations in Regulating Business', Centre for Analysis of Risk and Regulation, London School of Economics and Political Science, 3; Rahim, M. (2013). Legal Regulation of Corporate Social Responsibility, CSR, Sustainability, Ethics \& Governance, DOI 10.1007/978-3-642-40400-9_2, C) Springer-Verlag Berlin Heidelberg.
} 


\section{Conceptualisation of 'CSR', 'CG' and Corporate Regulation:-}

Contemporarily, it is generally recognized that the interaction between CSR and the law involves a degree of complexity ${ }^{6}$ and poses a series of challenges for legal normativity, which it places in a "new wrapper". CSR, as originally conceived, creates a "new normative space" in which hard law cohabits with soft law in an interpenetrating mix that creates links of supervision, dependency or autonomy. Because of this, normative networks take the place of the legal pyramid, and the continuum of the interaction between CSR and the law can range from encouragement, through incitation to constraint. Encouragement and incitation are generally voluntary and involve no sanctions, taking the form of "soft law" which has no obligatory effect and where application is not enforced through constraint. If constraint is introduced, the norms have an obligatory aspect and take the traditional form of binding regulations. Even today, the entrepreneurial practices and norms associated with CSR, widely used and imitated by competing businesses in the same sector often produce - fortunately or unfortunately, depending on the spectator's point of view - a form of law that is as soft as soft law when it ventures, through percolation, into the territory of hard law. For jurists, the lack of positive law is destabilizing, but it is less so once a few ways have been found to allow CSR to inter-penetrate the law. In fact, CSR and the law can maintain a close relationship, with several variations placed along a continuum. In the first variation, the law is used to formally structure CSR practices. The areas where CSR applies are all, without exception, subject to obligations specified by government regulation. In this approach, legislation compels businesses to adopt socially-responsible practices. This is the case, for example, for the well-known "comply or explain" rule applicable to CG, which requires companies to act transparently and makes them accountable for the social and environmental impact of their practices through reporting. ${ }^{7}$ In this way, they become socially accountable. The second way in which the links between CSR and the law becomes manifest is through the indirect inter-penetration of CSR with the law, without any formal upstream legal rules governing CSR practices. Another example is offered by environmental management systems (EMSs) ${ }^{8}$, developed in the 1970s in the wake of the first environmental legislation. The best-known are the Responsible Management Program and the ISO 14001 standard. The threat of penal or civil legal proceedings also plays a role in the motivation of businesses to set up a properly documented EMS. The documentation of environmental and social actions is at the core of the internal management system and can help the business if it has to plead due diligence in legal proceedings for a violation of an environmental law. The documentation, and its periodic verification, can be used to show that the businesses have acted diligently and have not been negligent. ${ }^{9}$ This is another example of a CSR practice introduced into the field of law. In fact, under this part, we will vividly consider the overview of CSR in general perspective and its nexus to Corporate Governance (CG) and corporate self-regulation (CR).

\section{The overview of corporate social responsibility:-}

The role of business in society is an ancient concern. ${ }^{10}$ However, until now this concern has not been conclusively determined; business communities and international civil societies have not yet been able to reach to an overall agreement ${ }^{11}$ when defining the responsibilities of companies to society. ${ }^{12}$ Indeed, defining CSR is complex and

\footnotetext{
${ }^{6}$ The relation between CSR and the rule of law is extremely complex, since in addition to the proximity and dialogue targeted, it may also result from a demarcation and even a marginalization of the rule of law. On this matter, refer to Isabelle Daugareith (2013).

${ }^{7}$ On this matter, refer to Sarbanes-Oxley Act (2002), French law known as Grenelle II (2010) and article L. 225-37 of the French Code de commerce.

${ }^{8}$ Halley, P. and Boiral, O. (2008). Les systèmes de gestion environnementale au Canada : enjeux et implications pour les politiques publiques de l'environnement. McGill LJ, 53, 649-685; Ruihua, J. and Bansal, P. (2003). Seeing the Need for ISO 14001.Journal of Management Studies, 40(4), p. 1050; Boiral, O. (2007). Corporate Greening through ISO 14001: A Rational Myth? Organization Science, 18(1), 127-146.

${ }^{9}$ Saxe, D. (1997). Voluntary Compliance: How Can Regulators Make It Work? Environmental Liability, 5, p. 80; Halley, P. (1999). La vérification environnementale : réflexions sur l'émergence des modes d'autorégulation. C. de D., 40(3), p. 637; Swaigen, J. (1992). Regulatory Offences in Canada: Liability \& Defences. Toronto, Ontario : Carswell. p. 132-137; Boy, L., La valeur juridique de la normalisation. In Clam, J. and Martin, G. (Eds.), Les transformations de la régulation juridique. Paris, France : Librairie générale de droit et de jurisprudence, p. 183.

${ }^{10}$ Warren, R. (2003). 'The Evolution of Business Legitimacy', European Business Review, 15(3), 153, 154; Gray, R., Owen, D. and Carol, A. (1996). Accounting and Accountability: Changes and Challenges in Corporate Social and Environmental Reporting, 1-2.

${ }^{11}$ Hopkins, M. (2004). 'Corporate Social Responsibility: An Issue Paper', Working Paper No. 27, Policy Integration Department, World Commission on Social Dimension of Globalisation.

http://www.ilo.org/integration/resources/papers/lang-en/docName-WCMS 079130/index.htm.
} 
contingent on situational factors. Moreover, there are an enormous number of varied definitions for CSR. One of the reasons behind the inconclusiveness of the definitions of CSR is rooted in its interchangeable and overlapping characteristics with other terminologies. ${ }^{13}$ Another reason may lie in the fact that the contemporary CSR agenda essentially involves the concept of stakeholders and development as an integral issue of business operations. Also, another reason is related to the ever-changing and dynamic character of CSR and its expansion of practices aligned with the increased demands from society and from development issues. ${ }^{14}$ Despite the inconclusive definitions, different approaches and many dimensions of CSR, the principal notions of this paradigm are almost established. Although these notions are not conclusive, they are consistent and have converged on common characteristics and similar elements. These are related to the economic, social and environmental impacts of business operations and their responses to customers' expectations, employees, shareholders and stakeholders in the context of these impacts. CSR is no longer confined to corporate philanthropy; rather, it has been established that accepting social responsibilities has a positive effect on companies' financial performances.

Cogently, CSR has established the core principles for furthering appropriate strategies for incorporating its different notions into business practice. This section, however, will not provide a thorough discussion on the definition of CSR, as this is believed to be a study in itself, and in this article no distinction is made between the different meanings attached to this term. Equally, the article is not focused on the philosophies in CSR; rather, it concentrates on identifying the core principles of CSR and suitable legal regulatory strategies to incorporate these principles into corporate self-regulation in weak economies. In this perspective, it can be accentuated that since CSR is a fluid concept $;{ }^{15}$ its interchangeable and overlapping character is dominant in its definition. To some scholars, this concept resembles the source of competitive advantage, while to others, it is 'an important response to the increasing demands of key stakeholders such as employees, investors, consumers and environmentalists. ${ }^{16}$ Besides, the precepts of CSR change with each generation, and its criteria could change according to the society in question. ${ }^{17}$ For instance, its meaning in the Continental European welfare society is different to its meaning in the USA or in developing or transitional societies. ${ }^{18}$ In the USA, companies consider philanthropy as a dominant factor of CSR, while in the Northern economies companies bear their social responsibilities by paying taxes. ${ }^{19}$ In these circumstances, a consistent terminology for this concept is yet to be developed. It is currently described using a number of terms: corporate citizenship, the ethical corporation, CG, corporate sustainability, socially responsible investment, corporate accountability and so on, and there is no overall agreement on its definition. ${ }^{20}$

For details, see Van Marrewijk, M. (2003). 'Concept and Definitions of CSR and Corporate Sustainability: Between Agency and Communion', Journal of Business Ethics, 44(2-3), 95,105.

${ }^{12}$ Snider, J. et al., in their article titled 'Corporate Social Responsibility in the 21st Century: A View from the World's Most Successful Firms' stated that an exact definition of CSR is elusive since beliefs and attitudes regarding the nature of CSR fluctuate with the relevant issue of the day. As such, viewpoints have varied over time and occasionally have even been opposing. See also Pinkston, T. and Carroll, A. B. (1996). 'A Retrospective Examination of CSR Orientations: Have They Changed?', Journal of Business Ethics, 15(2), 199, 207.

${ }^{13}$ Parliamentary Joint Committee on Corporations and Financial Services, Corporate Responsibility: Managing Risk and Creating Value, 2006, 4; for details, see Blowfield, M. and Frynas, J. G. (2005). 'Setting New Agendas: Critical Perspectives on Corporate Social Responsibility in the Developing World', International Affairs, 81(3), pp. 499, 501; Matten, D. and Moon, J. (2008). "Implicit" and "Explicit" CSR: A Conceptual Framework for a Comparative Understanding of Corporate Social Responsibility’, Academy of Management Review, 33(2), 404, 505.

${ }^{14}$ Snider, J. et al. (2003)., op cit. See also Pinkston and Carroll, (1996)., op cit. p. 207.

${ }^{15}$ Hopkins (2004)., op cit. p. 1; Marrewijk (2003)., op cit. p.105.

16 Bagi, A., Krabalo, M. and Narani, L. (2004). 'An Overview of Corporate Social Responsibility in Croatia', Zagreb: AED; Pinkston and Carroll (1996)., op cit.

${ }^{17}$ Kakabadse (2005)., op cit.

18 Daugherty, E. (2001). 'Public Relations and Social Responsibility', Handbook of Public Relations, 389, in Kakabadse (2005)., op cit. p. 280.

${ }^{19}$ Kakabadse (2005)., op cit. p. 280.

${ }^{20}$ Werther, W. and Chandler, D. (2010). Strategic Corporate Social Responsibility: Stakeholders in a Global Environment, 6; see also Bowfield and Frynas (2005)., op cit. 501; Matten and Moon (2008)., op cit. p. 505; Australian Parliamentary Joint Committee and Financial Service, Corporate Responsibility: Managing Risks and Creating Value, Report 2006, 4. 
The concepts underlying these terms are internally consistent and converge on certain common qualities and similar elements. In a broader sense, CSR is about the impact of business on a society or, in other words, the role of companies in the development of the society. In a narrower sense, it is a complex and multi-dimensional organisational phenomenon that may be defined as the extent to which, and the way in which, an organisation is consciously responsible for its actions (and non-actions) and the impact of these on its stakeholders. In this regard, the concept of CSR can be defined in various ways and may have different meanings. Altogether, Carroll, A. provided a long account of the evolution of the definition of CSR beginning from the 1950s and continuing through to the 1990 s with the specific features of each decade in terms of its development. ${ }^{21}$ In the 1980 s, as he mentioned, some alternative theoretical issues were added to the concept itself, including corporate social performance, stakeholder theory, and business ethics theory. ${ }^{22}$ In the definitional development that occurred in the 1990 s, these alternative themes took centre stage in the manifestation of $\mathrm{CSR}^{23}$ and all subsequent definitions were dominated by the stakeholder and societal approach, with the recognition of social, economic, and environmental issues as the basic components of responsibility. Therefore, the best illustration of this is available in the definitions and views developed in the late 1990s and subsequently by different intergovernmental, government and development organisations and some postmodern academics. ${ }^{24}$ The World Business Council for Sustainable Development defines CSR as 'the continuing commitment by business to behave ethically and contribute to economic development while improving the quality of life of the workforce and their families as well as of the local community and society at large. ${ }^{25}$ According to this definition, business societies have responsibilities to contribute to the development of their employees, their families, the local community and wider society to improve their quality of life and thus to try to ensure sustainable economic development. ${ }^{26}$ The phrase 'continuing commitment' used in this definition indicates that CSR is not a temporary issue that a company considers only in certain situations. Rather, it is a permanent issue that should be placed strategically within the policies and programs of companies. Business for Social Responsibility defines CSR in a more holistic way. This organisation refers to CSR as a tool for 'achieving commercial success in ways that honour ethical values and respect people, communities, and the natural environment. ${ }^{27}$ Thus, Business for Social Responsibility relates CSR to the idea of recognising and responding to a broader spectrum of stakeholder interests. The International Business Leaders Forum extends this idea and accepts it as a responsible business practice that could benefit business and society by maximising the positive impact business has on society while minimising the negative impact. In a similar fashion, a Green Paper published by the European Commission in 2001 defines CSR as 'a concept whereby companies integrate social and environmental concerns in their business operations and in their interactions with their stakeholders on a voluntary basis. ${ }^{28}$ Similarly, the World Economic Forum identifies the concerns for responsible business as follows: to do business in a manner that obeys the law, produces safe and cost-effective products and services, creates jobs and wealth, supports training and technology cooperation and reflects international standards and values in areas such as the environment, ethics, labour and human rights; to make every effort to enhance the positive multipliers of our activities and to minimise any negative impacts on people and the environment, everywhere we invest and operate. A key element of this is recognising that the frameworks we adopt for being a responsible business must move beyond philanthropy and be integrated into core business strategy and practice. ${ }^{29}$

\footnotetext{
${ }^{21}$ Carroll, A. (1999). 'Corporate Social Responsibility: Evolution of a Definitional Construct', Business and Society, 38(3), pp. 268-269.

${ }^{22}$ Ibid, p. 280; Freeman, E. and McVea, J. (2001). 'A Stakeholder Approach to Strategic Management', Blackwell Handbook of Strategic Management, 189.

${ }^{23}$ Carroll (1999)., op cit. p. 288; Gray, R., Owen, D. and Carol, A. (1996). Accounting and Accountability: Changes and Challenges in Corporate Social and Environmental Reporting.

${ }^{24}$ Dahlsrud, A. (2008). 'How Corporate Social Responsibility Is Defined: An Analysis of 37 Definitions', Corporate Social Responsibility and Environmental Management, 15(1), 1.

${ }^{25}$ Watts, P. and Lord Holme, (1999). Corporate Social Responsibility: Meeting Changing Expectations, 3.

${ }^{26}$ Ibid.

27 White, A. (2006). 'Business Brief: Intangibles and CSR', Business for Social Responsibility, 6, available at http://www.bsr.org/reports/BSR_AW_intangibles-CSR.pdf at 30 July 2010.

${ }_{28}$ European Commission, Green Paper: Promoting a European Framework for Corporate Social Responsibility, 2001, www.europa.eu.int at 5 July 2007.

${ }^{29}$ World Economic Forum, 'Global Corporate Citizen: The Leadership Challenge for CEOs and Boards', 2002,
} 
Comprehensively, given these definitions, CSR appears to be a managing element that starts at the company level by its performance in a socially responsible manner, where the trade-offs between the needs and requirements of different stakeholders are balanced and acceptable to all. ${ }^{30}$ In a recent publication, rather than giving any conclusive definition of CSR, the Australian Parliamentary Joint Committee on Corporations and Financial Services examined the concept of CSR from the following standpoints: (a) considering, managing and balancing the economic, social, and environmental impacts of companies' activities; (b) assessing and managing risks, pursuing opportunities, and creating corporate value beyond the traditional core business; and (c) taking an 'enlightened self-interest' approach to consider the legitimate interests of the stakeholders in CG. ${ }^{31}$ Equally, Michael Hopkins relates CSR 'with treating the stakeholders of the firm ethically or in a socially responsible manner. ${ }^{32}$ Here, the words 'ethically' and 'responsible' emphasise the notion that the treatment of stakeholders should be deemed acceptable in civilised society. According to Hopkins, this treatment of the stakeholder is an economic responsibility of companies. ${ }^{33}$ Marsden perceives CSR as a core behavioural issue for companies. He states that 'CSR is not an optional add-on nor is it an act of philanthropy; a socially responsible corporation is one that runs a profitable business that takes account of all the positive and negative environmental, social and economic effects it has on society. ${ }^{34}$ Also, Andersen defines CSR following a broader societal approach and states that the broader meaning of CSR relates to the extension of 'the immediate interest from oneself to include one's fellow citizens and the society one is living in and is a part of today, acting with respect for the future generation and nature. ${ }^{35}$ In fact, while other scholars have studied CSR, to respect space constraints and retain the focus on the main theme of this study, only the works of these three recent and well-cited scholars are mentioned here. ${ }^{36}$

Altogether, it should be reiterated as provided above that all of the definitions outlined confirm that there is no conclusive definition of CSR, and that it can have different meanings to different people and different organisations as an ever-growing, multifaceted concept. Nevertheless, it may be said that the concept of CSR is consistent and converges on certain common characteristics and elements. More precisely, if CSR as defined above is examined from a practical and operational point of view, it converges on two points. It requires companies (a) to consider the social, environmental, and economic impacts of their operations and (b) to be responsive to the needs and expectations of their stakeholders. ${ }^{37}$ These two points are also embedded in the meaning of the three words (i.e., 'corporate', 'social', and 'responsibility') of the phrase 'corporate social responsibility'. In this regard, the word 'corporate' generally denotes business operations, with the word 'social' depicting and covering all the stakeholders of the business operations, while the word 'responsibility' generally refers to the relationship between the business corporations and the societies within which they act together. It also encompasses the innate responsibilities on both sides of this relationship. Accordingly, it could be reaffirmed that CSR is an integral element of business strategy, that is, it is the way that a company should follow to deliver its products or services to the market; it is a way of

\footnotetext{
${ }^{30}$ Ibid; the definition of the Commission of the European Communities mentioned in the text were made in 2001. However, the later definition made in 2002 speaks broadly of CSR, stating: 'Corporate responsibility is about companies having responsibilities and taking actions beyond their legal obligations and economic/business aims. These wider responsibilities cover a range of areas but as frequently summed up as social and environmentalwhere social means society broadly defined, rather than simply social policy issues. This can be summed up as the triple bottom line approach, that is, economic, social and environmental.'

31 Australian Parliamentary Joint Committee on Corporations and Financial Services, Inquiry into Corporate Responsibility and Triple-Bottom-Line reporting for incorporated entities in Australia, 2005.

${ }^{32}$ Hopkins (2004)., op cit. p.1.

${ }^{33}$ Ibid.

${ }^{34}$ Marsden, C. (2001). The Role of Public Authorities in Corporate Social Responsibility, in Dahlsrud (2008). op cit.

${ }_{35}^{35}$ Andersen, K., The Project, (2003), in Dahlsrud (2008)., op cit. 11.

${ }^{36}$ Some other prominent works are: Carroll, A. (1991). 'The Pyramid of Corporate Social Responsibility: Toward the Moral Management of Organisational Stakeholders', Business Horizons, 34(4), 39; Carroll (1999)., op cit. p. 268; Conley, J. and Williams, W. (2005). 'Engage, Embed, and Embellish: Theory Versus Practice in the Corporate Social Responsibility Movement'.

${ }^{37}$ Fox, T. (2004). 'Corporate Social Responsibility and Development: In Quest of an Agenda', Development, Journal of Corporation Law 1, 29; Lockett, A., Moon, J. and Visser, W. (2006). 'Corporate Social Responsibility in Management Research: Focus, Nature, Alience and Sources of Influence', Journal of Management Studies, 43(1), 115; Moon and Vogel (2008)., op cit.; Buhmann, K. (2006). 'Corporate Social Responsibility: What Role for Law? Some Aspects of Law and CSR', Corporate Governance, 6(2), 188; Tung, C. (2006). The Legal Implications of CSR: Changing Landscape of Liability, at www.csr-asia.com/CGconference2006/ChrisTung.pdf.
} 
maintaining the legitimacy of corporate actions in wider society by bringing stakeholder concerns to the foreground; and a way to emphasise business concern for social needs and actions that go beyond philanthropy. We will, therefore, proceed with the core principles of CSR.

\section{The core principles of corporate social responsibility:-}

The 'triple bottom line' introduced by Elkington is one of the best-known models to discuss the core of CSR. ${ }^{38}$ In this model, the concept of CSR emphasises three responsibilities of a company: social, economic and environmental. These responsibilities are necessary to ensure economic prosperity, environmental quality and social justice. ${ }^{39}$ Also, Carroll identified four responsibilities which a company should accept to become socially responsible in a balanced way. According to him, a socially responsible company 'encompasses the economic, legal, ethical and discretionary expectations that society has of organisations at a given point of time. ${ }^{40}$ Another strong argument in the recent CSR practice literature relates to stakeholder engagement in CSR performance. In this regard, Freeman argues that companies have a responsibility to add their stakeholders to corporate activities. To him, stakeholder engagement is a vital way for companies to deal with their external environment effectively. ${ }^{41}$ Considering these major sources of CSR practices, they may be grouped into four major categories: the societal, environmental, economic and the stakeholder approaches. Indeed, each of these approaches has different perspective in terms of definitions and boundaries of responsibility. ${ }^{42}$ However, each of these approaches has their individual underlying principles. Briefly, the principle of the societal approach to CSR is that companies should contribute to building better societies and, therefore, should incorporate social concerns into their core strategies as well as consider the full scope of their impact on societies. More particularly, this principle requires companies to implement fair wage policies, uphold human rights, fair trade and ethical issues, produce safe products and cooperate in the network of companies and communities. $^{43}$ Also, the economic principle emphasises company efficiency in producing goods without compromising the social and environmental values. ${ }^{44}$ This principle denotes that along with their responses to the financial expectations of their shareholders, companies should focus on the economic wellbeing of society as a whole. ${ }^{45}$ While, the environmental principle, in short, states that the companies should not harm the environment in order to maximise their profits, and that companies should have a strong role in repairing environmental damage caused by their irresponsible use of natural resources. ${ }^{46}$ Finally, the principle of the stakeholder approach to CSR practice holds companies responsible for considering the legitimate interest of their stakeholders. ${ }^{47}$ These principles

${ }^{38}$ Elkington, J. (1998). 'Partnerships from Cannibals with Forks: The Triple Bottom Line of $21{ }^{\text {st }}$ Century Business', Environmental Quality Management, 8(1), 37; Rogers, M. and Ryan, R. (2001). 'The Triple Bottom Line for Sustainable Community Development', Local Environment, 6(3), 279; Juholin, E. (2004). 'For Business or the Good of All? A Finnish Approach to Corporate Social Responsibility’, Corporate Governance, 4(3), 20.

${ }^{39}$ Ibid; for a discussion on the implementation of these precepts in companies, see Thompson, G. (2005). 'Global Corporate Citizenship: What Does it Mean?', Competition and Change, 9(2), 131, 133.

40 Carroll, A. (1979). 'A Three-Dimensional Conceptual Model of Corporate Performance', Academy of Management Review, 497, 499-500.

${ }^{41}$ Freeman and John McVea (2001)., op cit. pp. 189, 24.

${ }^{42}$ Van Marrewijk (2003)., op cit. p. 95.

${ }^{43}$ Konrad, A. et al. (2006). 'Empirical Findings on Business-Society Relations in Europe', Journal of Business Ethics, 63(1), 89, 91; Carroll, A. (1999). 'Corporate Social Responsibility', Business \& Society, 38 (3), 268 ; Garriga, E. and Mele, D. (2004). 'Corporate Social Responsibility Theories: Mapping the Territory', Journal of Business Ethics, 53(1), 51; Valor, C. (2005). 'Corporate Social Responsibility and Corporate Citizenship: towards Corporate Accountability', Business and Society Review, 110 (2), 191; Van Marrewijk, (2003)., op cit. p.95; Siltaoja, M. (2006). 'The Relationship Between Corporate Social Responsibility and Corporate Reputation from a Value-Laden Viewpoint: An Empirical Study in a Finnish Newspaper Context', University of Jyvaskyla, 299.

${ }^{44}$ Konrad et al. (1999)., op cit., 89, 93.

45 McAdam, R. and Leonard, D. (2003). 'Corporate Social Responsibility in a Total Quality Management Context: Opportunities for Sustainable Growth', Corporate Governance, 3(4), 36; Matten, D. and Moon, J. (2007). 'PanEuropean Approach. A Conceptual Framework for Understanding CSR', Corporate Ethics and Corporate Governance, 179.

${ }^{46}$ Freeman, E. and Velamuri, R., 'A New Approach to CSR: Company Stakeholder Responsibility' Institute for Corporate Ethics Bridging Paper; Jamali, D. (2008). 'A Stakeholder Approach to Corporate Social Responsibility: A Fresh Perspective into Theory and Practice', Journal of Business Ethics, 82(1), 213.

47 Windsor, D. (2001). 'The Future of Corporate Social Responsibility', International Journal of Organizational Analysis, 9(3), 225; Jamali (2008)., op cit. 215. 
are the drivers of the sources of different CSR practices and hence important factors for initiating any strategies for developing CSR practices. ${ }^{48}$ These principles are used broadly within different segments of government, business and the academic world and are, thus, considered to be the cornerstone for the development of socially responsible corporate culture. Indeed, defining a paradigm is problematic and defining CSR is complex and contingent on situational factors. In fact, in its second generation, although CSR should have a universal definition, this has not yet been satisfactorily achieved. Thus, despite this, CSR has defined its principles, which are now acknowledged by standardisation regimes, global business societies, civil societies and nation states. Besides, the broad understanding of CSR is that companies should be committed to 'contribute to sustainable economic development - working with employees and their families, the local community and the society at large to improve the quality of life and sustainability, in a way that is also good for business. ${ }^{49}$ We will now consider the link between CSR and CG.

\section{The convergence of CSR and corporate governance ${ }^{50}$ :-}

There is an evolving interface between Corporate Governance (CG) and CSR. ${ }^{51}$ In fact, both these mechanisms hold economic and legal features, which may be altered through socio-economic processes in which competition within the product market is the most powerful force. ${ }^{52}$ Indeed, CG and CSR are complementary and are closely linked with market forces. Their objectives are not concurrent; they may act as tools for attaining each other's goals, though their setups as corporate frameworks are different. CSR operates in a free-form manner, whereas CG issues operate within well-defined and accepted structures. ${ }^{53} \mathrm{CG}$ is an umbrella term. ${ }^{54}$ In its narrower sense, it describes the formal system of accountability of corporate directors to the owners of companies. In a broader sense, the concept includes the entire network of formal and informal relationships involving the corporate sector and the consequences of these relationships for society in general. However, these two senses are not concurrent; but rather, they are complementary. Altogether, CG has been described as the ways in which suppliers of finance to corporations assure themselves of obtaining a return on their investment. ${ }^{55}$ However, it could also implicate 'the whole set of legal, cultural, and institutional arrangements that determine what publicly traded corporations can do, who controls them, how that control is exercised, and how the risks and returns from the activities they undertake are allocated'. ${ }^{56}$ Taking these senses together, CG is no longer merely about maximising stock value; rather, it concerns the "relationships among the many players involved and the goals for which the corporation is governed.' 57 In the usual CG framework, the roles, rights and responsibilities of corporate directors are vital. In particular, the board of directors is the most appropriate body to allow and design policies to enable corporate management to fulfil their responsibilities to society. ${ }^{58}$ In most cases, this board is the sole body that communicates corporate performance to corporate owners. Thus, with the beginning of the modern CSR era, ${ }^{59}$ its role in CG has vastly extended; Eisenberg described this as the 'board as manager'. ${ }^{60}$

${ }^{48}$ Ward, H. (2004). Public Sector Roles in Strengthening Corporate Social Responsibility: Taking Stock, 3.

49 Ibid.

${ }^{50}$ For details, see Rahim, M., 'Corporate Governance as Social Responsibility: A Meta-Regulation Approach to Incorporate CSR in Corporate Governance' in Boubaker, S. and Nguyen, D. (eds), Board of Directors and Corporate Social Responsibility, Palgrave Macmillan (UK).

${ }^{51}$ Mitchell, L., 'The Board as a Path Toward Corporate Social Responsibility' in McBarnet, D., Voiculescu, A. and Campbell, T. (2007). The New Corporate Accountability: Corporate Social Responsibility and the Law, 279.

${ }^{52}$ Shleifer, A. and Vishny, R. (1997). 'A Survey of Corporate Governance', Journal of Finance, 52(2), $737,3$.

${ }^{53}$ Mitchell, L. in McBarnet, Voiculescus and Campbell, (2007)., op cit. 279.

${ }^{54}$ For details on CG see Turnbull, S. (1970). 'Corporate Governance: its Scope, Concerns and theories', Corporate Governance, 5(4), 180; Hart, O. (1995). 'Corporate Governance: Some Theory and Implications', Economic Journal, 105(430), 678; Becht, M., Bolton, P. and Roell, A. (2003). 'Corporate Governance and Control', Handbook of the Economics of Finance 1, 1; Daily, C., Dalton, D. and Cannella, A. Jr, (2003). 'Corporate Governance: Decades of Dialogue and Data', Academy of Management Review, 28(3), 371; Bebchuk, L., Cohen, A. and Ferrell, A. (2009). 'What Matters in Corporate Governance?', Review of Financial Studies, 22 (2), 783.

${ }^{55}$ Shleifer and Vishny (1997)., op cit.737.

${ }^{56}$ Blair, M. (1995). Ownership and Control: Rethinking Corporate Governance for the Twenty-First Century, 3.

${ }^{57}$ Corporate Governance, http://en.wikipedia.org/wiki/Corporate_governance at 3 February 2011.

${ }^{58}$ Mitchell (2007)., op cit. 280.

59 For details of the corporate Board of Directors reform and the beginning of modern corporate social responsibility, see Mitchell (2007)., op cit. 284-288.

${ }^{60}$ Eisenberg, M. (1982). 'The Modernisation of Corporate Law: An Essay for Bill Cary', University of Miami Law Review, 37, 187, 209-10. 
Moreover, in the marketplace, CG is an old actor, whereas CSR is comparatively new. It is worth noting that the sophistication of consumers in the 1960s, the environmental movement of the 1970s and the increasing interest in the social impacts of business in the 1990s have all helped CSR reach the heart of CG. ${ }^{61}$ The list of key issues associated with this timeline is by no means comprehensive. However, it is aimed at highlighting some key initiatives over the last few decades that have contributed to the movement of CSR from the margins to the mainstream of the policy agenda. ${ }^{62}$ In almost every instance, these events did not specifically actuate CSR initiatives; rather, these instances set the global scene for the intersection between CSR and CG. Several of these events have been important drivers of this intersection: the global social urge to include the previously excluded social costs of production and the hidden costs incurred by the environment as a result of business activities with the corporate balance sheet; the lack of confidence in the institutions of the market economy ${ }^{63}$; and the demand for ensuring sustainable development. Equally, Kakabadse et al. identify 'consumerism' and 'corporate scandals' as the current most important drivers underpinning this development. ${ }^{64}$ These two factors are, indeed, closely related to market competition, and hence, they act as strong drivers for CG and CSR to develop the required framework by which a company can demonstrate its responsibility to the society at large through its performance.

Furthermore, to CG, this intersection largely contributes by reconciling the tension between CG's engagement with shareholder and stakeholder interest; it has become attuned to constituency concerns in CG. Also, to CSR, this intersection establishes CSR as: a business strategy to make the ultimate goals of corporations more achievable as well as more transparent; demonstrate responsibility towards communities and the environment; and take the interests of groups such as employees and consumers into account when making long-term business decisions. ${ }^{65}$ This convergence has incited arguments between the pro-regulation and the pro-business schools regarding the way in which a corporation ought to act in a socially responsible fashion. ${ }^{66}$ Indeed, to the pro-regulation advocates, an option that is commonly advanced is that the regulation of corporate directors' duties ought to be modified to incorporate an obligation for directors to consider social responsibilities at the core of corporate strategies. ${ }^{67}$ While the pro-business advocates fervently disagree with this notion and argue that burdening corporate directors with this type of liability may significantly disrupt the administration of CG laws as well as damn the socio-political compact. $^{68}$ They suggest, however, that the elected legislature is responsible for ensuring that corporations act in a socially responsible manner and that directors are responsible for ensuring that companies operating for long-term profit maximisation comply with regulatory constraints. ${ }^{69}$ To them, the consequence of this is that the legislature is responsible to the electorate, whilst directors respond purely to competitive pressures. Moreover, the potential convergence of CSR and CG, however, fuses the arguments of these two schools. It paves the way for CG to be driven by ethical norms and the need for accountability, and it enables CSR to adapt prevailing business practices. 'Where there were once two separate sets of mechanisms, one dealing with 'hard core' corporate decision-making and the other with 'soft core', people-friendly business strategies, scholars now point to a more hybridised, synbooked body of laws and norms regulating corporate practices. ${ }^{70}$ This has affected the modes of corporate regulation, that is, the 'hierarchical command-and-control' regulation" ${ }^{71}$ being replaced by a "mixture of public and

${ }^{61}$ Bagi, Krabalo and Narani (2004)., op cit.

${ }^{62}$ Ibid.

${ }^{63}$ Ibid.

${ }^{64}$ Kakabadse (2005)., op cit. 279; for a detailed study on this issue, see Thevenet, M. (2003). 'Viewpoint: Global Responsibility and Individual Exemplarity’, Corporate Governance, 3(3), 114.

${ }^{65}$ Gill, A. (2008). 'Corporate Governance as Social Responsibility: A Research Agenda', Berkeley Journal of International Law, 'Just Good Business', Economist, 26, 17 January, 452,463.

${ }^{66}$ See also Gettler, L. (2006). 'The Blurred Lines of Being Responsible', The Age 22 November.

${ }^{67}$ Levi-Faur, D. and Comaneshter, H. (2007). 'The Risks of Regulation and the Regulation of Risks: The Governance of Nanotechnology', New Global Frontiers in Regulation: The Age of Nanotechnology, 149.

${ }^{68}$ Greve, M. (2001). 'Business, the States, and Federalism's Political Economy', Harvard Journal of Law and Public Policy, 25, 895; Cioffi, J. W., 'The Corporation and Comparative Capitalisms: Corporate Governance Reform and the Regulatory Politics of Structural Change in the United States and Germany.'

${ }^{69}$ Corporations and Markets Advisory Committee, 'The Social Responsibility of Corporations' (Corporations and Market Advisory Committee, 2006) 111; Durden, C. and Pech, R. (2006). 'The Increasing Cost of Corporate Governance: Decision Speed-Bumps for Managers’, Corporate Governance, 6(1), 84.

${ }^{70}$ Gill (2008)., op cit. 463.

71 Lobel, O. (2005). 'Interlocking Regulatory and Industrial Relations: The Governance of Workplace Safety', Administrative Law Review, 57, 1071. 
private, state and market, traditional and self-regulation institutions" that are based on collaboration among the state, business corporations, and NGOs. ${ }^{72}$

Lastly, the convergence has gradually extended the narrower meaning of CG. It adds the agency focus to corporate ethics and accountability, and it relies on the 'business judgment' of CG to ensure this accountability. ${ }^{73}$ In this regard, it finds 'corporate self-regulation' as its dominant expression in the field of corporate conduct. On the ground, by adding issues such as human rights, workers' rights and environmental protection to 'self-regulation', CG has gained the opportunity to develop stakeholder engagement programs that could increase their competitiveness and to launch a marketing campaign that could emphasise their humanistic and democratic values as 'corporate citizens'. Indeed, in strong economies, corporate self-regulation has gradually absorbed the ethos of this convergence. In these economies, for instance, many companies have appropriate measures to internalise the costs externalised to the environment due to their business operations. ${ }^{74}$ These initiatives are not driven by laws; rather, they are driven by the corporate conscience to reduce costs as well as to contribute to environmental development. For instance, Wal-Mart has recently taken initiatives to 'green' its stores to reduce its energy and labour use. ${ }^{75}$ Also, between 2003 and 2008, Gap Inc. cut its greenhouse gas emissions by $20 \%$ and eliminated child labour from its suppliers. ${ }^{76}$ 3M's 3P program — 'Pollution Prevention Pay'-helped the company discover enormous savings that it had previously overlooked. ${ }^{77} \mathrm{John}$ Deere's recent foray into renewable energy is another prime example. Other than selling tractors, it provides financial support and consultation to help farmers harvest using wind energy. ${ }^{78}$ This may seem an odd fit, but the venture has become a source of value innovation as well as a way to meet social responsibilities; it is helping farmers to survive and creating a new revenue stream for the company. Indeed, a detailed discussion on how the governments of strong and developing economies are incorporating these principles into their companies is presented below.

\section{The conception and effects of corporate self-regulation:-}

In the age of globalisation, the authority and power of the nation-state has faced a dramatic decline. Non-state actors and transnational bodies are increasingly becoming engaged in constructing regulatory schemes and devices for businesses. $^{79}$ In this respect, corporate self-regulation, as motivated by international agencies, social groups, and business-related entities, has gained considerable interest due to its emergence as a complement to (if not a substitute for) formal governmental regulation. ${ }^{80}$ There is no single conception of self-regulation. It refers to any mechanism whereby a subject exercises control over itself to maintain the stability of its function. From the corporate regulation perspective, the broader meaning of this concept is that it is a part of the process of

${ }^{72}$ Gill (2008)., op cit. 464; for details on compliance management, financial regulation and administration at the corporate company level, see Orly Lobel, O. (2004). 'The Renew Deal: The Fall of Regulation and the Rise of Governance in Contemporary Legal Thought', Minnesota Law Review, 89, 263.

${ }^{73}$ Links between CG and CSR (Modified version of the chart presented in Jamali, D., Safieddine, A. and Rabbath, M. (2008). 'Corporate Governance and Corporate Social Responsibility Synergies and Interrelationship', Corporate Governance, 16 (5), 2008, 443, 447; Mitchell, 1. and Diamond, M. (2004). Corporations, a Contemporary Approach; Jamali et al. has examined the relationship between CG and CSR and find three bases for this relationship, namely: '(1) CG as a pillar for CSR; (2) CSR as an attribute of CG and (3) CG and CSR as coexisting components of the same continuum.' In this continuum, as Bhimani and Soonawalla described, the poor CG and misleading financial statements are one side of the corporate coin - the other side being poor CSR. For details see Jamali et al. (2008)., op cit. 443, 447; Bhimani, A. and Soonawalla, K. (2005). 'From Conformance to Performance: The Corporate Responsibilities Continuum', Journal of Accounting and Public Policy, 24, 165-74.

${ }^{74}$ Vogel, D. (2005). The Market for Virtue: The Potential and Limits of Corporate Social Responsibility, 14-46.

75 Pflum, M. (2007). 'Wal-Mart Commits to Going Green', ABC News 14 September; Schmit, J. (2010). 'Going Greener: Wal-Mart Plans New Solar Power initiative ', USA today 19 September.

${ }^{76}$ Gregory, S. (2009). 'Transparency: A Good Fit', Time 10 September.

${ }^{77}$ CSRpedia, 3P Pollution Prevention Pays, a CSR Program by 3M Co.

http://www.csrpedia.com/programs/3p-pollution-prevention-pays-229 at 19 May 2011.

${ }^{78}$ Esty, D. and Winston, A. (2009). 'Green-to-Gold-Plays'.

http://www.positivearticles.com/Article/Green-to-Gold-Plays/47943 at 19 May 2011.

${ }^{79}$ Cioffi, J. (2000). 'Governing Globalisation? The State, Law, and Structural Change in Corporate Governance', Journal of Law and Society, 27(4), 572.

${ }^{80}$ Parker, C. (2002). The Open Corporation: Effective Self-regulation and Democracy; Gunningham, N. and Rees, J. (1997). 'Industry Self-Regulation: An Institutional Perspective', Law and Policy, 19(4), 363. 
homeostasis by which a system regulates its internal environment to maintain a stable, constant condition by means of multiple equilibrium adjustment, by interrelated regulatory mechanisms. ${ }^{81}$ Its narrower meaning implies that self-regulation is the rules of business and the rights of practice set and enforced by a profession guild. This narrower meaning has been extended, and now this concept is no longer confined to professional organisations. ${ }^{82}$ It is widely applied in financial regulation and in many other sectors. It is now the 'plat du jour' in studies of regulation in many economies and an important element of the new learning. ${ }^{83}$ According to Gunningham and Grabosky, 'self-regulation is not a precise concept but, for the present purposes, it may be defined as a process whereby an organised group regulates the behaviour of its members. ${ }^{84}$ Also, Julia Black relates this concept to the concept of 'decentred' regulation. ${ }^{85}$ She, thus, identifies four basic forms of self-regulation: (1) mandated selfregulation; (2) sanctioned self-regulation; (3) coerced self-regulation and (4) voluntary self-regulation. ${ }^{86}$ In broad terms, mandated self-regulation denotes the mandates provided by the state to a collective group to formulate and enforce norms within a framework defined by the government; while in sanctioned self-regulation, a group formulates its own rules, which are then subjected to government approval. In coerced self-regulation, 'the industry itself formulates and imposes regulation, but in response to threats by the government that if it omits to do so the government will impose statutory regulation instead'. ${ }^{87}$ Equally, in voluntary self-regulation, the state is not involved in the regulatory strategies of the regulatees; instead, the regulatees take the initiative in the formation and operation of their regulatory system. ${ }^{88}$ All these modes of self-regulation serve different objectives in internal regulation and contribute to increased ownership and responsibility at the same time; they help to develop internal regulatory mechanisms capable of minimising the cost of compliance.

In fact, within this panorama, a highly visible and frequently debated form of self-regulation is the corporate code of conduct. In contrast to private business codes that deal with transactional and contractual aspects of commerce, codes of conduct address corporate ethics, moral guidelines, and key CSR issues like human rights, labour, the environment, and sustainable development. ${ }^{89}$ Throughout the 1990 s, these codes were adopted by large companies, particularly those with a strong presence in developing economies with weak state-based regulatory systems. ${ }^{90}$ These codes are the main self-regulatory instrument for companies; they address corporate conduct with respect to their external social, environmental, human rights and economic factors. Hence, these codes are largely focused on sectors where brand reputation and export orientation are vital. Codes relating to labour issues usually align with the footwear, garment, sporting goods, toy and retail sectors, while those related to environmental aspects are likely to be present in the oil, chemical, forestry and mining industries. ${ }^{91}$ Sources suggest that the world's larger multinational companies and buyers have taken the lead in adopting such codes, which can perform as dependable sources ${ }^{92}$ and alternative means of regulation. ${ }^{93}$

${ }^{81}$ See http://iit.ches.ua.edu/systems/homeostasis.html, mentioned in Spencer, E. (2008). 'Reconceiving the Regulation of the Franchise Sector' Macquarie Law Journal, 8, 103, 106.

${ }^{82}$ Ogus, A. (1994). Regulation: Legal form and Economic Theory, 107

${ }^{83}$ Ramsay, I. (2006). 'Regulatory Capitalism and the "New Learning" in Regulation', Sydney Law Review, $28,9$.

${ }^{84}$ Gunningham, N., Grabosky, P. and Sinclair, D. (1998). Smart Regulation: Designing Environmental Policy, 50.

${ }^{85}$ Black, J. (2002). 'Decentring Regulation: Understanding the Role of Regulation and Self-Regulation in a "PostRegulatory” world', Current Legal Problems, 54, 103, 118.

${ }^{86}$ Ibid.

${ }^{87}$ Hertogh, M. and Westerman, P. (2009). Self-Regulation and the Future of the Regulatory State Manuscript: International and Interdisciplinary Perspectives, 19.

${ }^{88}$ Black (2002)., op cit. 27; for details, see Hertogh and Westerman (2009)., op cit.

${ }^{89}$ Wymeersch, E. 2006. 'Corporate Governance Codes and their Implementation', Gent University.

${ }^{90}$ Arthurs, H. (2005). Private Ordering and Workers' Rights in the Global Economy: Corporate Codes of Conduct as a Regime of Labour Market Regulation, Labour Law in an Era of Globalisation: Transformative Practice and Possibilities, 471.

${ }^{91}$ United Nations Research Institute for Social Development, Corporate Social Responsibility and Business Regulations: How should Transnational Corporations be Regulated to Minimise Malpractice and Improve their Social, Environmental and Human Rights Record in Developing Economies? 2004, www.unrisd.org

${ }^{92}$ Xiaoyong, H. (2006). Corporate Codes of Conduct and Labour Related Corporate Social Responsibility: Analysing the Self-Regulatory Mechanisms of Multinational Enterprises and their Impacts to Developing Countries, The Japan Institute for Labour Policy and Training, http://www.jil.go.jp/profile/documents/Hu.pdf at 23 July 2010.

${ }_{93}$ Julian, L. (2006). 'Adoption of Corporate Social Responsibility Codes by Multinational Companies', Journals of Asian Economics, 17(1), 50, 51. 
Indeed, in this light, two major critiques have risen in regard to codes of conduct. The first of these concerns the legal pluralism and free market ideology underlying self-regulation. ${ }^{94}$ It has been argued that since codes of conduct are based on the principles of legal pluralism and free market ideology, economic players in the private sphere use this form of self-regulation to fulfil their own interests. This mode of regulation creates a tendency to view private ordering systems as pursuing their own policies rather than public policy goals. ${ }^{95}$ The second critique contends that codes of conduct have almost always failed to improve corporate behaviour worldwide, and thus are hypocritical in their purpose. ${ }^{96}$ Indeed, many agree that these codes, even when supported by a strong monitoring system, might not generate ground-level change, unless accompanied by fitting changes in business culture and decision-making. ${ }^{97}$ In response, advocates of codes of conduct propose arguments that the analysis of these codes' potential for engendering change requires more complex doctrinal and empirical understanding. ${ }^{98}$ They argue that the new institutional economic approach has gradually supported the integration of CSR and business cases since CSR not only represents costs for the company but also results in various advantages. To reap the benefits of these advantages, companies depend upon their codes of conduct. They argue that corporate codes of conduct can positively affect sales, purchasing and recruitment of new staff. ${ }^{99}$

Moreover, these codes of conduct can aid Corporate Governance (CG) to secure their company's reputation, create innovation and increase motivation among their employees, leading to the increased sustainability of their company. Hence, CG creates a corporate code of conduct not just as a nominal part of their strategic communications. ${ }^{100}$ Another recent trend in self-regulation that has drawn attention is its feature of non-financial reporting. First published in the $1990 \mathrm{~s}$ in response to a series of environmental disasters, non-financial corporate reports are now increasingly covering a much wider range of corporate policies. ${ }^{101}$ This trend seeks to not only inform the public of existing CSR policies implemented by the reporting firm but also to provide incentives for companies to ensure transparency and create channels for dialogue with their stakeholders. ${ }^{102}$ In other words, besides corporate disclosure, the advantage of non-financial reporting is that it encourages CG to consider and incorporate better mechanisms for long-term accountability to their constituencies. ${ }^{103}$ Nevertheless, such reporting is still largely a voluntary concept, despite recent attempts to mandate it. Some companies have chosen to incorporate CG and CSR issues into their annual financial reporting, creating what has become known as 'integrated reports.' ${ }^{\text {, }}$ Both Bothe codes of conduct and non-financial reporting trends exemplify how corporate self-regulation serves as a significant medium for connecting governance with responsibility. Through various strategies and instruments, self-regulation has subjected businesses to a mix of supervisory principles that reflects the convergence of CG and CSR. External stakeholders have an important role in the supervision of corporate self-regulation and corporate codes of conduct. This has helped the development of a 'standardisation regime'; with large companies now depending on this regime to ensure that their suppliers are fulfilling, or are able to fulfil, CSR practices following a set of international standards commonly known as the multi-stake holder codes.

${ }^{94}$ Blackett, A. (2000). 'Global Governance, Legal Pluralism and the Decentered State: A Labour Law Critique of Codes of Corporate Conduct', Indiana Journal of Global Legal Studies, 8, 401.

${ }^{95}$ Palzer and Scheuer (2003)., op cit.

96 Locke, R. and Romis, M. (2006). 'Beyond Corporate Codes of Conduct: Work Organisation and Labour Standards in Two Mexican Garment Factories'.

${ }^{97}$ Progressive Corporate Law (1995)

98 Zumbansen, P. (2006). 'The Parallel Worlds of Corporate Governance and Labour Law', Indiana Journal of Global Legal Studies, 13(1), 261.

99 Tomsen, S. (2005). 'Encouraging Public Private Partnerships in the Utilities Sector', NEPAD/OECD.

${ }^{100}$ Blowfield and Frynas (2005)., op cit., 512; for the factors that relate corporate codes of conduct to the business case see Fox (2004)., op cit.

${ }^{101}$ Kolk, A. (2008). 'Sustainability, Accountability and Corporate Governance: Exploring Multinationals' Reporting Practices', Business Strategy and the Environment, 17(1), 1.

${ }^{102}$ Hess, D. (2007). 'Social Reporting and New Governance Regulation: The Prospects of Achieving Corporate Accountability through Transparency', Business Ethics Quarterly, 17, 455, 458.

${ }^{103}$ See, Elkington, J. (2001). The Triple Bottom Line for 21st-Century Business, The Earthscan Reader in Business and Sustainable Development.

${ }^{104}$ Kolk (2008), op cit. 
Emphatically, it could be appreciated that these codes are readily allowing divergent CSR practices to be bundled into 'generic management systems standards' for business corporations. ${ }^{105}$ Indeed, the convergence of CSR and CG at the macro level plays an important role in this development; this convergence has driven companies to create commercial value for a standardisation regime. The organisations that are creating and nourishing these initiatives have gradually created norms for standardising sets of CSR practices for companies. The increasing acceptance of multi-stakeholder codes by companies, and civil society organisations' affiliation with these codes have further developed a standardisation regime that can help companies to demonstrate their efforts towards fulfilling their social, economic, environmental and ethical responsibilities. The development of CSR standardisation has also allowed the establishment of many organisations specialising in diverse initiatives to facilitate entrepreneurs' ability to do business in a more socially acceptable way. These organisations have detailed different social, ethical and environmental standards to evaluate corporate performance in society, as well as to enumerate the social responsibilities of companies. ${ }^{106}$ In this regard, the convergence of CSR and CG has readily helped to develop the standardisation regime. Correspondingly, most global companies have acknowledged this development and are exclusively considering certain of these initiatives to measure their suppliers' performance. Some of them weed out suppliers from their chains on the results of performance tests based on these initiatives. Using these initiatives, they select strategic suppliers to: reduce their transaction costs; increase their profitability; reduce costs as a result of a reduced need to switch suppliers; and increase their competitiveness in the marketplace through improved relationships with consumers. ${ }^{107}$

\section{The impact of CSR and CG convergence on corporate regulation:-}

There are different regulatory systems in the corporate regulation landscape. ${ }^{108}$ Amongst these systems, public regulation, self-regulation and co-regulation are prominent. In fact, public regulation denotes the traditional form of regulation where public authorities set the relevant legislation or other forms of binding actions for the purpose of achieving public policy aims. In this system, legislation is adopted to set the necessary rules, monitor compliance and impose sanctions to aid in enforcing these actions. This form of regulatory system also details the structures, tasks and means for the involvement of private citizens and organisations in the implementation of its rules. Nevertheless, the responsibility for implementing these rules remains with the state. ${ }^{109}$ While self-regulation is the opposite of public regulation; indeed, as Julia Black defines, self-regulation is 'the situation of a group of persons or bodies, acting together, performing a regulatory function in respect of themselves and others who accept their

${ }^{105}$ Gawel, A. (2006). Corporate Social Responsibility: Standards and Objectives Driving Corporate Initiatives.

${ }^{106}$ ISO Standard Series, SA8000, AA1000, ETI Base Code are some examples of prominent initiatives for standardising CSR practices. Like these initiatives, there are many other that have contributed to the development of a number of codes on particular CSR issues and monitoring and verification procedures. The Workplace Code of Conduct and Principles for Monitoring of the Fair Labour association has developed internal and independent monitoring procedures to promote labour standards in the workplace in the USA and worldwide apparel industries. Similarly, the Clean Clothes Campaign has adopted a code of conduct with a view to improve working environments in the global suppliers' factory premises, including garment and sportswear industries. The Global Reporting initiative has provided a framework for reporting on the basis of triple bottom lines, which refers to companies' social, economic and environmental impacts. In addition, under the auspices of the United Nations Global Compact, learning and networking.

${ }^{107}$ Ibid.

${ }^{108}$ Defining regulation is difficult as this term is employed for a myriad of discursive, theoretical, and analytical purposes. Moreover, it is highly contested. For this article, regulation is defined for any process or set of processes, as Colin Scott states, by which "norms are established, the behaviour of those subject to the norms monitored or fed back into the regime, and for which there are mechanisms for holding the behaviour of regulated actors within the acceptable limits of the regime'. This definition relates to the principles of 'new governance' and the 'new regulatory state' where one of the objectives of regulation is to capture the plurality of interests and sources of control around issues, problems and institutions. For details, see Scott, C. (2001). 'Analysing Regulatory Space: Fragmented Resources and institutional Design', 283; Scott, C. (2004). Regulation in the Age of Governance: The Rise of the Post-Regulatory State, the Politics of Regulation: Institutions and Regulatory Reforms for the Age of Governance; Black, J. (2002). 'Decentring Regulation: Understanding the Role of Regulation and Self-Regulation in a "Post-Regulatory" World', Current Legal Problems, 54, 103; Gunningham, N. (2009). 'The New Collaborative Environmental Governance: The Localisation of Regulation', Journal of Law and Society, 36(1), 145; Levi-Faur, D. (2010). 'Regulation and Regulatory Governance', Hebrew University, 8-9.

${ }^{109}$ Palzer, C. and Scheuer, A. (2003). 'Self-Regulation, Co-Regulation, Public Regulation', Promote or Protect, 165. 
authority'. ${ }^{110}$ In this regulatory system, social groups such as producers, providers and so on create their own regulatory system in order to reach their objectives. In this system, private parties take the responsibility for monitoring compliance, and public authorities usually do not interfere in the regulatees' self-monitoring strategies. When considering the implementation phase, this regulatory system can be divided into two levels, that is, selfregulation at the macro level and self-regulation at the micro level. In fact, at the macro level, self-regulation may have technical and qualitative standards related to codes of conduct that define good and bad practices in internal regulation. ${ }^{11}$ These standards may be provided by a self-regulatory organisation created by the parties concerned. ${ }^{12}$ Indeed, at this level, the rule-making power (the regulator) is separated from the rule-applying power (the regulatee). While at the micro level, the regulatee is solely responsible for both the rules and implementation strategies. Here, the key feature of this mode of regulation is that the regulator and regulatee are identical, and therefore the regulatee enjoys the scope of framing their own internal strategies to reflect the public policy goal and the norms of the code of conduct in a given circumstance.

Moreover, in its widest sense, the term co-regulation means 'cooperative forms of regulation that are designed to achieve public authority objectives - the cooperation being performed by public authority and civil society. ${ }^{113}$ However, in its narrowest sense, it means that the regulator and the regulatee are linked by a regulatory scheme designed to reach a public policy goal as well as to fulfil the interests of the regulatee. In this light, it can be appreciated that a co-regulatory scheme combines elements of self-regulation, self-monitoring and traditional public regulation strategies. Indeed, in co-regulation, there can be many different forms of regulatory strategies depending on the combination of elements of the public authority and private sector. Nonetheless, in this regulatory system, the public authority generally lays down the legal basis so that the system can begin to function, and the private parties develop the rules that describe its functioning. In fact, the impact of the convergence of CSR and CG has mostly been reflected by the development of self-regulatory (micro-level) regimes in the business environment. Explicitly, corporate self-regulation is an increasingly important part of business regulation. ${ }^{114}$ In this perspective, advocates of this convergence believe that corporate self-regulation that contains the principles of CSR offers opportunities to companies for greater market access, cost savings, productivity and innovation, as well as broader social benefits such as education and community development. ${ }^{115}$ In the same token, at the level of the individual company, the notion of corporate self-regulation is usually enshrined either through its own code of conduct or through its incorporation of a multi-stake holder initiative or guidelines prepared by another social or commercial organisation. Indeed, in the part, we will focus on what readily result from the interaction between CSR and CG with Corporate Regulation in the OHADA zone in particular.

\section{Contextualisation of CG and CSR Under the OHADA Law:-}

In a political environment like Cameroon and other member states of the OHADA zone, there are three principal reasons for trying to create a serious and sophisticated regime of laws to control businesses. The first of these reasons is that people in the zone do bring suits. Indeed, conversations with lawyers and business people who have engaged in litigation confirm that the professionals expect litigation to progress in what in the developed countries, would be considered a relatively normal fashion; to the extent that the relevant law is clear and well-adapted to commercial realities; thus, making it less likely that incompetence will lead to inappropriate decisions. The second reason is that lawyers who behave professionally, or at least appear to do so, are patterning behaviour that may in time substantively affect social norms. While some judicial decisions reflect a profound misapprehension of the underlying law, others to the contrary, evidence a careful and sophisticated reading of the texts. To the extent that lawyers and their clients are expressing great concern about the system and, thus, tend to focus not on the OHADA substantive law but instead, on the national legal regime's handling of judgments to be executed. Interestingly, even in so difficult a legal environment, the effort to analyze law appears to enhance and reward professionalism. While the third reason concerns the concept of CSR under OHADA, which deserves great articulation. Indeed, it should be appreciated that various aspects of the OHADA statutes have reflected the importance of employees as a social

${ }^{110}$ Black, J. (1999). 'Constitutionalising Self-Regulation', Modern Law Review, 59(1), $24,27$.

${ }^{111}$ Palzer and Scheuer (2003)., op cit.

${ }^{112}$ Ibid., 166.

${ }^{113}$ Ibid., 170.

${ }^{114}$ Clark, J. (2003). Worlds Apart: Civil Society and the Battle for Ethical Globalisation; Hutter and O’Mahony (2004)., op cit. 3.

${ }^{115}$ Lobel, O. (2010). Crowding Out or Ratcheting Up? Fair Trade Systems, Regulation, and New Governance, Fair Trade, Corporate Accountability and Beyond: Experiments in Globalising Justice, 313. 
value. For example, in the uniform act on bankruptcy procedures, unsecured wage earners recover on liquidation ahead of secured interests. ${ }^{116}$

Similarly, "corporate interest" as an expression of CSR almost certainly instruct managers to include employees in the constituencies for whom they operate the business. In this regard, if the courts of OHADA's member states and the CCJA adopt a broadly encompassing definition of corporate interest, managers may well be required to take into consideration the interests of the community affected by the business. In fact, in the United States, this kind of obligation exists only in the most unusual and egregious circumstances and is imposed by laws other than corporate law. For example, suits charging environmental discrimination can force a business to consider the surrounding community. But under OHADA, it is the company law itself whose understanding of corporate interest can include environmental impact. The inclusion of the environment within the concept of corporate interest ultimately will depend at least in part on social and political realities. Again, the relationship between CG as the manifestation of CSR, and political governance proves to be very close. Conceptually that is a defensible outcome, at least so long as the political governance at issue is itself defensible. For example, if the political input accurately reflects social realities, which generally will mean that the political realm is relatively democratic, businesses will more likely reflect the wishes of the body politic.

Altogether, the citizenry of the seventeen (17) OHADA states could conclude that much of their countries' exports are from the extractive industries, and that the nations have a long-term interest in preserving natural resources. In this way, all the OHADA member states can then impose the same costs on potential investors, both domestic and foreign. They can assert that foreign investors and domestic investors cannot use business forms to poach animals or timber. On the other hand, if the governments are relatively undemocratic, the political power may well be in the hands of persons who will instead seek rents by collaborating with the extractive industries. In that situation, the political oligarchs, arguably acting for their own purposes against the interest of the people, exert their power to influence the countries to adopt a narrower vision of corporate interest. The point is that the OHADA regime's commercial and company laws offer its member states an opportunity to serve their citizens' own long-term interests. To achieve this result, however, this article articulates that there is need to focus on corporate governance and political governance to harmonize the standards inherent in the company law to the existing social norms. This, therefore, requires a discussion among all social constituencies.

\section{The impact of corporate governance under OHADA:-}

In addition to the eight uniform business acts referred to in the introduction, OHADA provides various supranational institutions, including a legislature and a court. The legislature, the Council of Ministers, is made up of the member countries' justice and finance ministers. The supranational court - the Common Court of Justice and Arbitration (CCJA), receives appeals from the member-states' national courts on matters relating to the OHADA law. ${ }^{117}$ The CCJA's decisions are published both on paper and on the internet, ${ }^{118}$ thereby introducing some transparency from the top and simultaneously protecting the laws' uniformity of interpretation and application. This is the juridical context of the OHADA law. However, as is the case in the developed countries, the OHADA company law contains provisions to constrain management. These provisions are particularly relevant when management is separated from ownership. Therefore, to follow a modern trend, present also in the United States, the OHADA law does recognize that many businesses do not have the split between management and ownership which readily gives rise to governance issues. Besides, under OHADA, it is worth noting that even the business form that can be used for a public as well as a private company, the "société anonyme", can have a single owner. Thus, so long as there are no more than three owners, there can even be a single manager who, whether or not an owner, can have authority to exercise Board functions plus those of the senior executives. ${ }^{119}$

\footnotetext{
${ }^{116}$ See OHADA bankruptcy law, Articles $95 \& 166$ (concerning the privilege of salaried employees and priorities). Seewww.ohada.com.

117 See Traité relatif à l'Harmonisation en Afrique du Droit des Affaires, 4 Journal Officiel (JO) OHADA 1 (November 1, 1997), available at http://www.ohada.com/traite.php?categorie=10 (hereinafter "OHADA Treaty").

118 The official site of OHADA's executive branch, the Permanent Secretariat, is www.ohada.org. A private website sponsored by various donor organizations is as of the date of this writing more complete. See www.ohada.com.

${ }^{119}$ Administrateur Général; OHADA UA Article 385 (single shareholder possible); Article 494 (single administrateur général); OHADA UA Article 495 (the single administrateur general need not be a shareholder). See www.ohada.com.
} 
Indeed, where management is separated from ownership, scholarship and cases under OHADA frequently interpret those laws using standards applicable to French company law. For example, management is not to abuse its rights, and expressly, neither the majority nor minority shareholders, now in a quasi-management role, are to abuse their power. ${ }^{120}$ More generally, the management of a company formed under OHADA does have the obligation to disclose to the owners, important matters and issues of conflict of interest, and to monitor the business. Instead of relying on the fiduciary duty, however, OHADA tends to enlist formal structures and apply express rules. For example, OHADA provides a centralized registry and insists on the publication of essential filings. When the registry is finally computerized, it will be a source of substantial disclosure. These requirements are serious, that is, organizational forms that otherwise shelter owners from liability will lose that ability if they fail to register and publish constitutive documents as required by the company law. Businesses that do not offer limited liability also must file with the register. This applies even to sole proprietors, that is, any natural person who is active in business, as statutorily defined, is obliged to file, this time as a "trader" ('commerçant'). The OHADA law specifies the rights and obligations among such traders. ${ }^{121}$

Further, a business organization that is like a general partnership except formed only upon a filing with the registry, can have only "traders" as its members, thus requiring double disclosure. The registry's jurisdiction is broader than receiving and posting filings at formation. It also centralizes information concerning a business's operations. For example, it records various forms of secured interests, including mortgages. In this way, too, the structure forces disclosure. As does the company law of developed countries, OHADA also values monitoring. However, it again relies on the structure more than on the fiduciary-like standards to accomplish its goal. Thus, for on-going operations of a certain size, a combination of disclosure and monitoring is imposed by official, statutory auditors. ${ }^{122}$ These are more regulated and constraining than are the classic certified public accountants who serve as auditors in the United States. The statutory auditors also have an affirmative duty to monitor and warn, if they find that the business is in imminent danger. ${ }^{123}$ In summary, therefore, governance under OHADA functions rather like governance under the US law, except that OHADA forces greater disclosure and tends to use rules and external structures rather than standards like fiduciary duty.

\section{The context of corporate social responsibility under OHADA:-}

It is one thing to say that managers are to disclose and monitor, and quite another to determine what kinds of behaviours are to be disclosed and monitored. As we have seen, the CG constraints are designed to support and enhance underlying values. These values, as noted above, are embodied in the concept of CSR. That is why, in the United States, management must exercise its disclose-monitor duties so as to maximize shareholder wealth. According to scholarship, OHADA takes a different tack; instead of endorsing shareholder primacy, it embraces a form of the French "intérêt social." ${ }^{124}$ Regression toward the mean suggests that the likely outcome for OHADA is a moderate flavour of the doctrine: neither will the OHADA company be limited to owner's primacy, nor will it include an obligation to the society at large. In this regard, management probably will owe an obligation not only to shareholders, but to other integral constituencies such as the employees, and perhaps suppliers and customers. Indeed, in developing economies, it may be relatively simple for management to take into account the interests of employees, for example, as well as shareholders. Employees, because they invest their human capital and cannot generally be well diversified, will tend to have a long time-horizon. In a closely held environment, the owners, too, are probably reasonably undiversified and may well, thus, have a relatively long-term view of the company and its needs. Because very few businesses in a developing economy are publicly traded, in most cases the interests of the owners and employees will be aligned at least to the extent that neither constituency is looking for short-term, extractive returns. Nevertheless, there will certainly still be areas of non-alignment for management to negotiate-

${ }^{120}$ OHADA Uniform Act, Articles 130 \& 131. Seewww.ohada.com.

121 Droit Commercial Général UA, Articles 2-7; 19 (definition of « commerçants »and stipulation of obligation to file with the register); DCG Article 202 (contracts under this AU apply only to "commerçants"); Company law UA, Article 270 (all owners of a "société en nom collectif” are « commerçants »). Seewww.ohada.com.

${ }^{122}$ Company law UA, Article 694 (statutory auditor). Seewww.ohada.com.

${ }^{123}$ Company law UA, Articles. 150,153,157 (describing warning system). Seewww.ohada.com.

${ }^{124}$ See, e.g., Koné, M. (2003). Le Nouveau Droit Commercial des Pays de la Zone OHADA ; Compariasons Avec Le Droit Français 16, (noting that OHADA's concept of corporate interest is based on the French system). See also supra Part II.A.2.b (discussion of French company law's adoption of corporate interest as a form of corporate social responsibility). 
the amount of wages to be paid being an obvious example. ${ }^{125}$ Business in any form, however, does not work in a vacuum. Indeed, after taking this quick tour of the few concepts concerning governance and social responsibility under OHADA; we will now consider the CSR realities that an OHADA-organized business faces.

\section{The incorporation of CSR in OHADA Law:-}

Now that the notion of CSR has been placed in its historical and conceptual context, this section of the article will look at how, in practical terms, CSR could be incorporated into the normative law of the OHADA zone. In this light, two questions of a prospective nature arise immediately. Firstly, on what normative basis could the CSR idea be incorporated into the OHADA law? And secondly, how and using what normative instrument? Indeed, to answer the first question, we need to scrutinize the normative and teleological foundations of the OHADA law while thinking about how to incorporate CSR; whereas for the second question the solution will probably come from a review of possible receptacles. It goes without saying that all the potential solutions scattered throughout this section and the subsequent ones, must take into account the objectives, specific features and dynamics of the OHADA law. In fact, by its construction ${ }^{126}$ and nature ${ }^{127}$, the OHADA law is an innovative model that is not based, in a normative manner, on economic integration, but instead creates a legal and judicial zone. The Port Louis Treaty ${ }^{128}$ established, in an unprecedented and original way, a legal and judicial zone within which various non-exhaustive matters belonging in principle to the field of business law were standardized ${ }^{129}$ across various states in Sub-Saharan Africa $^{130}$, these states, while belonging to this new legal and judicial zone, also remain members of various regional and community organizations. More importantly, it is commonly accepted that the main objective of OHADA is economic in nature, since it is intended to encourage economic development in member states by stimulating foreign investment through the creation of a secure legal and judicial zone. As a result, the aims of the OHADA law can be considered as a triptych: (1) to establish legal and judicial security; (2) to enhance attractiveness; and (3) to ensure economic development. A statement by one of the "founding fathers" of OHADA, the late Hon. Kéba M'baye, reveals much about the key economic objective underlying the OHADA law. He asserted that "OHADA is a legal tool designed and created by Africa to serve the cause of economic integration and growth." In the same token, Xerexhe provides that this teleological and economic goal for OHADA law is confirmed by doctrine and almost unanimously accepted. ${ }^{131}$ As a tool for economic development, OHADA aims to "regain investor trust and secure legal relationships to ensure sustainable growth."132

${ }^{125}$ See infra Part II.B.3 discussing how the broadest definition of corporate interest could obligate management to protect the environment.

${ }^{126}$ See Article 1 of the OHADA Treaty states that its objective is the harmonisation of business laws in the Contracting States by the adoption of common rules described in Article 5 as "Uniform Acts". The Uniform Acts passed to date related to (1) commercial law, (2) commercial companies and economic interest groups, (3) securities, (4) simplified recovery procedures and measures of execution, (5) collective proceedings for wiping off debts, (6) arbitration, (7) the organization and harmonization of undertakings' accounting systems, (8) contracts for transportation by road, and (9) cooperative societies.

${ }^{127}$ OHADA does not establish either a customs union or a common market within the meaning of WTO law; it is an original organization for legal integration of the 3rd type, an "inter-state organization that is a source of inter-state law". On this matter, refer to Droit, liberté, paix, développement. Mélanges Madjid Benchikh. (Doumbé-Bile, 2011). ${ }^{128}$ OHADA was created by the Treaty on the Harmonization of Business Law in Africa (1997) J.O. OHADA, 4, p. 1, signed at Port Louis (Mauritius) on October 17, 1993, which came into force in 1995. It was revised by the Treaty of Quebec in Canada dated October 17, 2008, which came into force on March 21, 2010.

${ }^{129}$ Although the Port Louis Treaty mentions the idea of harmonization, it has been shown that the process is one of standardization rather than harmonization. On the distinction between the degrees of legal integration resulting from harmonization, unification and standardization, see Antoine Jammeaud (1998).

${ }^{130}$ OHADA is currently composed of seventeen (17) states mainly in French-speaking Africa (Benin, Burkina-Faso, Cameroun, Congo Brazzaville, Côte-d'Ivoire, Gabon, Guinea-Bissau, Equatorial Guinea, Mali, Niger, Central African Republic, Chad, Togo, and Comoros). The Democratic Republic of Congo is the last state to have joined OHADA, on July 13, 2012.

${ }^{131}$ Xerexhe, E. (1999). L'intégration juridique comme facteur d'intégration régionale. Revue burkinabé de droit, 39.

${ }^{132}$ Diakhate, M. (2003). Les procédures simplifiées et les voies d'exécution : la difficile gestation d'une législation communautaire. Retrieve from www.ohada.com. 


\section{The receptiveness of OHADA Law to the social dimension:-}

When joining the aims of OHADA with the objectives of CSR, one question needs to be asked: Will a normative framework that enables the promotion of CSR also increase legal security and economic attractiveness in the OHADA zone, while helping to make businesses more innovative and more competitive? In our view, the answer can only be affirmative, for three reasons. Firstly, the incorporation of CSR into the OHADA law will at last open it up to the possibility of social teleology, which is indispensable at the dawn of a new century; secondly, the momentum appears appropriate, since it coincides with a pause to take stock of the situation in several OHADA projects; lastly, the international context of which OHADA is a part, and from which it could avoid being excluded, makes this receptiveness necessary. Thus, to begin with, the development of legal norms on the integration of social and environmental concerns into economic activities is essential if the OHADA law is to strengthen the growing level of trust in the economies of its member countries. This appears to be necessary in order to respond to the needs of modernity and adaptability subscribed to and emphasized in the Port Louis Treaty ${ }^{133}$ to ensure receptiveness and the effectiveness of the OHADA rules ${ }^{134}$.

Firstly, the incorporation of CSR into the OHADA law may make a major contribution to its modernity and adaptability, in particular, if a conception of CSR based on the stakeholder theory is adopted. Indeed, according to the stakeholder theory ${ }^{135}$, a business must consider a range of interests in its decision-making process including, in a holistic way, all stakeholders such as shareholders, workers, the State, local communities, consumers and suppliers. Altogether, the interests protected in this regard, usually go beyond the economic and speculative interests to include the social and environmental aims such as the protection of the environment, social development and human rights, which will help make economic growth sustainable over time. Thus, the stakeholder approach appears to us to be the most nuanced and suitable to guide the establishment of CSR in a zone such as the OHADA zone, by seeking the convergence between the interests of all stakeholders, among which are social wellbeing and the environment. This reflects the contingency of the notion of CSR previously referred to in the first part of this article. Indeed, contingency does not need to be discussed here and it is admitted that to better reflect the specific features of the economies of developing countries such as the OHADA states, characterized by increasing vulnerability, CSR must focus more on the primary needs (food, water supply, basic social services, etc.), the strengthening of group and individual work relationships, the protection of the socio-cultural and ecological environment and the fight against corruption and consideration for the specific needs and aspirations of local communities.

Secondly, the momentum, which coincides with a phase of stagnation ${ }^{136}$ or in-depth reflection ${ }^{137}$ about the OHADA projects and plans ${ }^{138}$, may offer an opportunity for opening up the law in this legal and judicial zone to take account of a key social dimension that until now has been somewhat neglected. This period of reflection concerning certain OHADA projects can be put to good use to include a review of the aims of the OHADA law and a later receptiveness to the guidelines that include the social, environmental and human rights aspects-especially, since the Treaty that established the OHADA offers membership to any member state of the African Union; ${ }^{139}$ even one that has not signed the treaty. Equally, membership is also open to any State that is not a member of the African Union, as specified in the first paragraph of Article 53 of the constituting Treaty setting out the OHADA's PanAfrican vocation.

Thirdly, an examination of the international context shows that the CSR concept has been mentioned, since the start of the 2000s, as one that can contribute to economic and social development. Sustainable development is founded, in fact, on the principle of integration and, therefore, on the necessity, for international organizations, regional

133 Treaty on the harmonization of business law in Africa, 1993, Preamble para. 1, 4 and Art. 2.

${ }^{134}$ Gatsi, J. (Ed.). (2006). L'effectivité du droit de l'Ohada. Yaoundé, Cameroun : Presse universitaire d'Afrique; Kodo, M. (2010). L'application des Actes uniformes de l'Ohada. Louvain, Belgium: Académia Bruylant.

${ }^{135}$ Freeman, R. E. (1984). Strategic Management: A Stakeholder Approach. Boston, Mass: Pitman.

${ }^{136}$ Pougoué, P-G. and Elongo, Y. (2008). Introduction critique à l'Organisation pour l'harmonisation en Afrique du Droit des Affaires. Presses Universitaires d'Afrique.

${ }^{137}$ Toé, J. (2008). La problématique actuelle de l'harmonisation du droit des affaires par l'OHADA. Revue de droit uniforme, 13 (1-2), p. 32.

${ }^{138}$ Several Uniform Act projects launched in recent years are currently on hold, such as the Projet d'acte uniforme relatif au droit du travail, au droit des contrats, au droit de la consommation etc.

${ }^{139}$ Formerly known as the OAU: Organisation of African Unity, created on May 25, 1963 in Addis Ababa, Ethiopia. It later became the African Union. 
organizations such as OHADA, states and businesses, to incorporate social and environmental concerns when making economic decisions. Based on the principle of integration, the economy, the environment and social development must strengthen each other. This is the objective set out in the preamble to the Agreement Establishing the World Trade Organization (WTO), which mentions that sustainable development is one of the goals pursued by the WTO Agreement. The mutual reinforcement of development and the environment provides extra motivation to incorporate CSR within the OHADA zone. The conceptual framework for sustainable development is another factor legitimizing the CSR concept and a broad dissemination of its practices.

Moreover, in June 2000, the OECD also noted the link between CSR and sustainable development when it adopted the OECD Guidelines for Multinational Enterprises, updated in 2011. The Guidelines were preceded by the OECD Declaration on International Investment and Multinational Enterprises. ${ }^{140}$ The OECD Guidelines for Multinational Enterprises are the most complete document existing today on the subject of corporate responsibility. The European Commission, in turn, formally recognized the link between CSR and the implementation of sustainable development in a 2002 publication, preceded by a Green Paper in July 2001 called "Promoting a European framework for CSR", in which it defines CSR as "a concept whereby companies integrate social and environmental concerns in their business operations and in their interaction with their stakeholders on a voluntary basis." In fact, it was intended, firstly, to launch a debate on the concept of CSR and, secondly, to explore ways to build a partnership for the development of a new European framework for the promotion of CSR. Also, CSR involves the socially responsible management of change within an enterprise. This result is achieved when the enterprise makes an effort to strike a balanced, generally acceptable compromise between the requirements and needs of all the stakeholders. Thus, if enterprises can manage change in a socially responsible way, then they will have a positive impact at the macroeconomic level. Lastly and more recently, in 2012, the United Nations declared its support for "national regulatory and policy frameworks that enable business and industry to advance sustainable development initiatives, taking into account the importance of corporate social responsibility"141. In other words, the United Nations explicitly encourages regional organizations such as the OHADA to introduce the necessary institutional and legal mechanisms to promote the emergence and adoption of CSR practices by enterprises.

\section{The indications of CSR under the OHADA Uniform Act:-}

By and large, it is one thing to say that managers should disclose and monitor, whereas it is quite another to determine what kinds of behaviours need to be disclosed and monitored. As we have seen so far, CG constraints are designed to support and enhance the underlying values. These values, as noted above, are embodied in the concept of CSR. That is why, in countries like the USA, management must exercise its disclosure and monitor duties, so as to maximise shareholders' wealth and protect other stakeholders. In this regard, the society has not only sanctioned the business to operate according to the profit motive, but the business is expected to comply with the laws and regulations promulgated by the state as the ground rules under which the business must operate. Indeed, as a partial fulfilment of the social contract between the business and the society, firms are expected to pursue their economic missions within the framework of the law. In this regard, legal responsibilities reflect a view of codified ethics in the sense that they embody basic notions of fair operations as established by lawmakers. So, to this effect, does the law actually allow CSR by corporations? In fact, traditionally, corporations are formed to carryout business transactions in anticipation of profit making to benefit the owners. Every jurisdiction where corporations operate has its own law on corporate governance. But remarkably the corporate design contained in hundreds of corporate laws throughout the world is nearly identical. That design creates a governing body to manage the corporation, and dictates the duties of the directors. In fact, these laws create corporate purpose, which is to operate the business in the interest of shareholders. Altogether, the OHADA Uniform Act on companies and economic interest groups provides that 'a commercial company shall be formed in the common interest of the partners'. ${ }^{142}$

Similarly, like most provisions in other jurisdictions like the American Business Corporation Act, which provides inter alia that "the directors and officers of a corporation shall exercise their powers and discharge their duties

\footnotetext{
${ }^{140}$ The Declaration was adopted by the governments of the OECD member countries on June 21, 1976. It was revised in 1979, 1984, 1991, 2000 and 2011. (http://www.oecd.org/fr/daf/inv/politiquesinvestissement/declarationdelocde.htm). The Declaration include guidelines: National Treatment instrument, Conflicting requirements and International investment incentives and disincentive.

${ }^{141}$ In the Final Report of the United Nations Conference on Sustainable Development, Rio+20, entitled "The Future We Want", par. 46.

${ }^{142}$ See the OHADA Uniform Act on Commercial Companies and Economic Interest Groups 1998, Article 4 para.2
} 
with a view to the interests of the corporation and of the shareholders...."143 This is not different from the English Common Law position where directors are required to act bona fide in what they consider is in the best interest of the company. ${ }^{144}$ The fall out of these legal positions is that those who manage the corporation must put the interest of the corporation first. The corporation's main interest is the maximization of its profit or that of its members. These provisions dedicate the corporation to the pursuit of its own self-interest and undoubtedly equate the corporation's self-interest with shareholder's self-interest. No mention is made of the responsibility to public interest. There are certainly two fall outs from these provisions; firstly, they explain why corporations find social issues like human rights irrelevant because they fall off the corporation's legal mandate and secondly, these provisions explained why executives behave differently than they might as individual citizens, because the law says their only obligation in business is to make money. This design of the provisions has the unfortunate side effect of largely eliminating social responsibility. ${ }^{145}$ Because corporate law generally regulates corporations but not executives, it leads executives to become inattentive to justice. They demand their subordinates 'to make the numbers' and pay little attention on how they do so. Directors and officers know their jobs, salaries, bonuses and stock options depend on delivering profits for shareholders. ${ }^{146}$

Therefore, most corporate donations or social activities were carried out as philanthropic gestures only to the extent that they could be seen to contribute to the profit of the corporation. In fact, under traditional English Common Law, such philanthropic acts were not tolerated, as they were seen to be ultra vires the company. In this regard, Bowen, $L$. stated in Hutton v. Brunner Mond \& $\mathrm{Co}^{147}$ that 'charity cannot sit at the boardroom table and the fact that there are to be no cakes and ale except for the benefit of the company'. This aptly defines the English position as concerns CSR. The ultra vires doctrine which was to the effect that any act done by the company which was not part of its objects could not be held to be that of the company, if the third party suffered under that act. This, therefore, meant that for any CSR act to have been made, it ought to be enshrined as part of the objectives of the corporation. This put management in a very difficult position, as they would have been held personally liable for any acts that were outside the objects of the company. Thus, this in no way could help the course of CSR. This situation was not only limited to acts with third parties but also even related to actions concerning employees of the corporation. This was the case in Parke v. Daily News ${ }^{148}$ where it was held that to use the proceeds of sale of the defunct News Chronicle and the Star News Papers to compensate employees who lost their jobs was ultra vires, since the company business had ended. This decision led to a huge outcry and little response by legislature ${ }^{149}$ so the courts in subsequent decisions tried to narrow the former perceived position of "ultra vires" the "constructive notice rule" was inherent practices that went to protect nothing but the interest of the corporation and had no regards for public interest. This led to a reformation of the ultra vires doctrine by law. ${ }^{151}$

Aptly, the new position of English Law, favours any person dealing with the company in good faith; any transaction decided on by the directors should be deemed to be within the capacity of the company and free from any limitations under the Memorandum and Articles of Association on the powers of the directors and this relieved the other party of any obligation to inquire these matters. ${ }^{152}$ In this regard, perhaps the delegation of powers to the directors and the reformation of the ultra vires doctrine are the widest latitudes that the law has given to directors of corporations in UK to commit the company to CSR. This is because the directors who may embark on any CSR activity with issues that could well be regarded as falling under the powers delegated to the directors will leave the members helpless before it, as the directors are not bound to seek any ratification of actions

\footnotetext{
${ }^{143}$ Ibid, Article 7- 6

${ }^{144}$ Lord Greene M R, in Re Smith and Fawcett Ltd. 1942, Ch. 304CA, p.306

${ }^{145}$ Hinckley, R. (2002). 'How corporate law inhibits Social Responsibility: A Corporate Lawyer proposes a Code of Corporate Citizenship. Business Ethics: Corporate Social Responsibility Report, (January/February), p.1

146 Ibid

${ }^{147}$ Hutton v. Brunner Mond \& Co (1883) 23 ch. D 654CA, p.673.

148 Parke v. Daily News (1962) ch. 927.

${ }^{149}$ Companies Act 1980, s.74; now Companies Act 1985, s.719 and the Insolvency Act 1986, s.187.

${ }^{150}$ Charterbridge Corpn. V. Lloyds Bank (1970) ch. 62, Re Halt Garage Ltd (1986) 3 All EeRr 1016; Re Horsely\& Weight Ltd (1982) CH.442, CA; Rolled Steel Ltd v. British Steel Corporation (1986) ch. 246, CA. They established that ultra vires should be limited to the question whether the company has acted within its capacity, depending on the construction of the objects cause and if it acted within the objects.

${ }^{151}$ Davies, P. (1997). Gowers., Principles of Modern Company Law, 6th ed, Sweet and Maxwell, pp.207-220

${ }^{152}$ Companies Act 1985 Section 35; Section 3A(b) and Section 15
} 
that fall within their scope. The most, the members can do is to dismiss the directors and appoint others in their place or alter the articles so as to restrict the powers of the directors. This English position almost reflects the Cameroon's situation today in particular. For obvious reasons, the Cameroon legislation as applicable in the English-speaking regions before the entry into force of the OHADA treaty was similar, if not at times same, as the English position while the French speaking regions were applying the French position of - 'intérêt social'. But with the entry into force of the OHADA Treaty and the consequential Uniform Act on Commercial Companies and Economic Interest Groups (OHADA Uniform Act), the position has somewhat shifted. The Uniform Act provides that members of the management organs of the company, directors and managing directors, within the limits provided by the Uniform Act for each form of company, shall have full powers to commit the company with respect to third parties, without having to show proof of a special instrument granting such powers. Any limitation of their legal powers by the Articles of Association shall not be demurable to third parties. ${ }^{153}$

Correspondingly, this undoubtedly buries the "constructive notice doctrine" in all transactions between the corporate management and the rest of the world. However, this position differs from the English position where such third parties will only be spared liability, if they acted in good faith with the company. Perhaps, in addition to the above provision, the corporate management could rely on the provision of Article 122 of the OHADA Uniform Act to carry out CSR and would not be completely breaking corporate rules. This Article provides that; "the company shall be bound by the acts of its managers, directors and administration which are unrelated to the company's object." 154 In this light, daring directors who are pro-CSR may hide behind the above provisions to exercise the powers that could be regarded as helping the course of CSR. But here, as in other jurisdictions, it is not expected that management will become 'Father Christmas' and give away any corporate property. ${ }^{155}$ Indeed, any action under the law as it is will only be objectively justified and must not be seen as capable of jeopardizing the corporate existence. However, some corporations may not take it kindly with any CSR acts, as to them, this amounts only to waste of resources and will only have to sanction management involved in it. The question that remains is, how many or what percentage of management staff would be ready to embark on such actions that will cause them loss their jobs? In fact, it is very unlikely that this risk will be taken and as such CSR would not be readily enhanced appropriately.

\section{The procedure to incorporate CSR as part of OHADA Law:-}

Emphatically, the greatest question now is; how can CSR standards be incorporated into the OHADA law? In this regard, we will provide a lucid answer to this question in this section; where we will elaborate as reiterated above that the current OHADA legal corpus does not need to be rearranged or changed to act as receptacle for a CSR norm. Indeed, following the revision of the OHADA constituting Treaty in 2008 in Quebec City, Canada; the opening and content for a CSR norm within the body of the OHADA law can be appreciated and considered in Article 27. In this light, the incorporation of CSR provisions into the OHADA law can be appreciated in the opening provided in Article 27 of the OHADA Treaty. As such, the 2008 revision created this opportunity by establishing the Conference of Heads of State and Government to "rule on any matter relating to the Treaty". Indeed, in our view and given the objective of OHADA which is to organize the harmonization of business law in Africa, this text empowers the new organ - the Conference of Heads of State and Government, to introduce provisions on CSR since they are supplemental to business law, or may simply be included under Article 2 of the Treaty as an "other matter". In the same token, the same power to rule on any matter relating to the Treaty also provides the opportunity to establish a specialized CSR body. In fact, proposals to this effect were made during the CEMAC. The creation of a sub-regional CSR rating agency was one of the recommendations made at the workshop held in Congo. In connection with the creation and implementation of a CSR standard for extraction industries, a "CSR policy guide" is appended to the overview of the proceedings of the national workshop held in Yaoundé. ${ }^{156}$ Equally, the $2^{\text {nd }}$ "International Forum for CSR Pioneers and Inclusive Green Growth in Africa" held in Tunis in 2012 was resounding. This Tunis proceedings notes, in paragraph 7, that "since the CSR approach is only just emerging worldwide, the construction of a vision of economic, social and environmental responsibility for enterprises in

\footnotetext{
${ }^{153}$ See Article 121, Uniform Act on Commercial Companies and Economic Interest Groups 1998

${ }^{154}$ Ibid., Article 122

${ }^{155}$ Lukong, A. (2010). Corporate Social Responsibility: A favour or an obligation, African Law Review, vol.7, No.1, pp.141-14

${ }^{156}$ CEMAC (2013). Projet de création et de mise en œuvre d'un standard RSE pour les industries extractives en zone CEMAC. Retrieved from http://www.cemac.int/sites/default/files/synthe\%CC\%80se_travaux_atelier_yaounde.pdf
} 
Africa will be more inclusive if it takes into account the specific features of the land, the context, the national legislations, the international references and the related jurisprudence." ${ }^{\prime 157}$

The possible normative instruments of CSR under the OHADA:-

Since "CSR has emerged as a field conducive to legal innovation in a context of globalization"; 158 the normative instruments suitable for inclusion in OHADA law should be available. In this regard, two hypotheses are possible, and we prefer the second, as more ambitious, of the two. The first hypothesis, which can be considered "nonambitious", would involve introducing private international CSR norms into the OHADA law, by including a reference in the legislative text of member states. The second and more ambitious strategy, which we dearly support, would be to adopt a Charter along with CSR Guidelines for the OHADA zone, following discussions coordinated by a transnational CSR committee and consultations with stakeholders in the member states. The effects of this legal instrument on the OHADA law and the organizations to which it would apply (state-owned corporations, international enterprises) would be based on the values expressed in the Charter by the 17 OHADA member states. Indeed, the adoption of an OHADA CSR Charter, along with an OHADA CSR strategy and plan of action, would readily form part of the international commitments made by the OHADA member states to promote economic development, human rights and environmental protection. In fact, this initiative would greatly contribute to the objective of introducing methods that would identify the CSR practices that could be used to attract investment to Africa, and thus, increase the value of the economic sectors in order to enhance the confidence of investors and stakeholders.

Moreover, the inclusion of CSR as a component of the OHADA law must be discussed and structured in a way that ensures that the OHADA Charter, Strategy and Plan of Action on CSR reflect trends in the various economic sectors, their current and future growth, and current and planned foreign investment in each sector. A strategy designed to influence public policy, laws, regulations and programs must propose strategic guidelines for the planning and implementation of institutional and other instruments to facilitate the establishment of CSR practices, before the practices are developed by enterprises. CSR, and its ethical, environmental and economic values, could in this way be placed at the heart of the economic development of the OHADA member states. Indeed, by seeking to give concrete expression to the objectives of an OHADA Charter on CSR, the Organization must introduce guidelines, upstream, to place the social and environmental responsibility of enterprises not as a constraint on economic development, but rather as a key element in the economic, social and environmental development of the member states that will contribute to the wellbeing of their population. The initiative will help give effect to Article 24 of the "African Charter on Human and Peoples' Rights" by guaranteeing the right of peoples to a satisfactory environment, and the recent "African Charter on Democracy, Elections and Governance" ratified by some OHADA member states. In fact, Article 33 of the Charter refers to enterprises and states that "State Parties shall institutionalize good economic and corporate governance through, inter alia: (6) Equitable allocation of the nation's wealth and natural resources; (7) Poverty alleviation; (8) Enabling legislative and regulatory framework for private sector development; (9) Providing a conducive environment for foreign capital inflows". Altogether, to enhance the wellbeing of the African population, enterprises are required to take responsibility for workers' health and safety and the need to hire part of the national labour force, and to take into account the services that the environment provides free of charge for the private sector. This would readily assist the development of several economic sectors in the member states.

Finally, the viable implementation of the objectives of a possible "OHADA CSR Charter" and the key guidelines in the "OHADA CSR Strategy and Plan of Action" would enhance the sustainability of several economic sectors in this part of the continent. Concern for the wellbeing of workers and the protection of the environment are increasingly important given the growing power of the emerging economies that invest in Africa and that will be able to do so, while undertaking to respect human rights, social development in Africa, and the environment, three dimensions that, when they are taken into consideration, help make investments more secure and sustainable. In a new approach based on CSR, the efficiency of investments and economic development models and practices must no longer be measured solely in terms of economic effectiveness but also in terms of their ability to satisfy stakeholders by meeting human needs and protecting the environment. As noted above, over the last ten years, CSR "has re-emerged

\footnotetext{
${ }^{157}$ Institut Afrique RSE \& CONECT (2012). Manifeste de Tunis. Retrieve From http://www.institut-afrique-rse.com/images/PDF/Manifestedetunis.pdf.

${ }^{158}$ Daugareith, I. (2013). Le droit à l'épreuve de la RSE. In C. Gendron \& B. Girard (Eds.), Repenser la responsabilité sociale de l'entreprise. L'école de Montréal (Chap. 11). Paris, France : Armand Colin.
} 
as an open, multi-form concept that is still under construction" ${ }^{\prime 159}$. In this regard, OHADA could contribute and become a player in this construction project in Africa's business community. More importantly, to achieve this, the plan of action accompanying the OHADA CSR Charter and Strategy must target comprehensive, rather than sectoral, goals to ensure that government departments and agencies work to include, as part of their various economic activities, objectives to promote CSR practices by enterprises. These concerns must be reflected in the institutional practices established or modified by OHADA. Equally, while recommending and clamouring for the eminent putting in place of the viable OHADA CSR Charter and Strategy, it is of great interest for the various OHADA member states to put in place pre-emptive and sustainable CSR legislations that could aid in providing resounding social responsibility solutions to the various stakeholders for the main time, thus, providing the enabling and conducive atmosphere for the eventual emergence of the OHADA CSR Charter and Strategy.

\section{Conclusion:-}

It has been highlighted that the developed world has highly evolved and sophisticated legal constraints on managerial behaviour - in terms of corporate governance (CG). However, against this backdrop there also exist compatible social constraints, which have readily failed from time to time - where failure means that managers are exercising their authority so as to cause the business to act contrary to the underlying norms of CSR. In this regard, the United States for instance, has modified the legal constraints to shepherd business conduct back toward the shareholder primacy. Contrariwise, the developing world to some extent with its weak legal system, relies more on the extra-legal constraints than on the law to channel the behaviour of managers. Thus, it is worth noting that the underlying definition of CSR, too, is more obviously influenced by cultural norms. Law, in this context, has social influence chiefly to the extent that it becomes a virtual forum for the discussion of the socio-legal norms and a vehicle for reinforcing professionalism. By casting themselves back on the social bedrock rather than on laws, the developing countries underscore concepts that are too easily forgotten in the developed countries. The experiences in the developing countries emphasize that $\mathrm{CG}$ is not a first principle, but that it merely implements socially constructed values collected under the concept of CSR. For developing countries, the CG laws also offer a forum and a vocabulary for discussing with the political authorities what should be the applicable standards. But for the developed countries, we can learn from these realities that any conception of CSR currently being applied by courts is fundamentally political and needs to be revisited in the context of the evolving social expectations. Equally, developing countries tell us that the definition of CSR deserves a public debate, and that concepts of CG cannot be divorced from the underlying purpose of the business organization.

As the article has explicitly shown, the OHADA law, thanks to its openness and malleability, would be able to incorporate and integrate norms based on CSR, given the contingency of a concept characterized as a socioeconomic melting-pot. The review of the origin and evolution of CSR demonstrates its adaptive capacity and its ability to take into account the social, cultural and economic realities of the zone in which it applies. The study of CSR as a notion revealed one of its essential attributes, namely additionality. The interaction between the OHADA law and a mechanism based on CSR does not contradict the worldwide movement towards co-regulation, characterized by cohabitation and coexistence, aiming at a balance between the voluntary and restrictive norms and between the public and private initiatives that recalls the state imperium. This mixity and hybridization constitute the essence of the postmodern law governing CSR, as attested by this statement by Daugareith - a specialist in the field: The normativity introduced by supra-national CSR may be seen not as a form of degeneracy of the law but as participation in the evolution of the law, a right in gestation, in statunascendi. It is possible to consider that these new forms of regulation extend the scope of the law. The international soft law on which CSR is currently founded and makes it possible to explore a new field for legal regulation, while at the same time expressing the awareness of the international community of the need for legal regulation of the activities of globalized business. ${ }^{160}$ Because of this, the normative principles contained in the future OHADA CSR Charter should be based on the legitimate aspirations of the African population with respect to transparency, good economic governance, fair access to basic necessities, water and food, the sustainable management of abundant natural resources, and improved living conditions in local communities, in particular through involvement in the decision-making process and economic activities of multinational enterprises.

${ }^{159}$ Acquier, A. and Gond, J. (2007). Aux sources de la responsabilité sociale de l'entreprise : à la (re)découverte d'un ouvrage fondateur, Social Responsibilities of the Businessman d'Howard Bowen. Finance Contrôle Stratégie, 10(2), 5-35.

${ }^{160}$ Daugareith, (2013)., op cit. 